\title{
PROTUPRAVNOST KAO PRETPOSTAVKA ODŠTETNOPRAVNE ODGOVORNOSTI U HRVATSKOM PRAVU
}

Prof. dr. sc. Marko Baretic**

UDK: $347.441 .82(497.5)$

$347.511(497.5)$

DOI: $10.3935 /$ zpfz.70.5.02

Izvorni znanstveni rad

Primljeno: listopad 2020.

U radu se, kroz prizmu sudske prakse, analiziraju neka temeljna pitanja vezana uz protupravnost u hrvatskom odštetnom pravu kao što su: je li protupravnost pretpostavka odgovornosti za štetu, и čemu se protupravnost sastoji, na što se protupravnost odnosi, u kakvom je odnosu s krivnjom kao pretpostavkom odgovornosti te na temelju kojih kriterija se protupravnost utvrduje. Analiza hrvatske sudske prakse, koja je provedena u ovom radu, nedvosmisleno upućuje na to kako je protupravnost puno složeniji i dinamičniji institut od onoga što sugerira hrvatska pravna književnost. $U$ tom smislu provedena analiza sugerira kako prilikom utvrdivanja protupravnosti štetnikova ponašanja sudovi često prosuđuju neke subjektivne elemente koji se u pravnoj književnosti vežu uz krivnju. Nadalje, analiza također pokazuje da prilikom procjene protupravnosti štetnikova ponašanja sudovi često vode računa o nizu elemenata poput naravi i važnosti prava $i$ interesa na koje se odnosi konkretan slučaj, stupnja opasnosti vezane uz određenu aktivnost, stupnja povrede zaštitnih propisa, dostupnosti alternativnih metoda zaštite, o predvidlivosti nastupanja štetnog događaja, ali i o međudjelovanju različitih elemenata konkretnog slučaja. Sve to navodi autora na zaključak da je pojam protupravnosti, kako se on tumači u domaćoj sudskoj praksi, iznimno blizak francuskom institutu faute.

Ključne riječi: protupravnost, odštetno pravo, pretpostavke odgovornosti za štetu

* Dr. sc. Marko Baretić, profesor Pravnog fakulteta Sveučilišta u Zagrebu, Trg Republike Hrvatske 14, 10000 Zagreb; marko.baretic@pravo.hr;

ORCID ID: orcid.org/0000-0001-8182-0315 


\section{UVOD}

Hrvatska pravna književnost beziznimno navodi protupravnost kao jednu od temeljnih pretpostavka odgovornosti za štetu. ${ }^{1}$ Pritom, u pravnoj se književnosti uobičajeno navodi kako je protupravnost sadržajno i funkcionalno složen institut koji inkorporira objektivni i subjektivni element. Objektivni element protupravnosti predstavlja protivnost štetnikova ponašanja nekom pravilu objektivnog prava, dakle nekoj normi pravnog poretka. Subjektivni element protupravnosti predstavlja krivnju. ${ }^{2}$ I dok se za protupravnost u objektivnom smislu navodi da je riječ o općoj pretpostavci odgovornosti za štetu, koja mora biti ispunjena u pogledu bilo koje vrste odgovornosti za štetu, za krivnju, odnosno protupravnost u subjektivnom smislu, navodi se da je riječ o posebnoj pretpostavci koju je potrebno ispuniti isključivo u slučajevima subjektivne odgovornosti za štetu. ${ }^{3}$

Unatoč činjenici da predstavlja jednu od temeljnih pretpostavka odgovornosti za štetu, protupravnost očito nije pobuđivala znatniji interes naše pravne književnosti pa je teorijskopravna obrada ovog instituta relativno skromna. Osim u jednom monografskom djelu ${ }^{4} \mathrm{i}$ jednom članku pravne analitike posvećenom problemu protupravnosti u jednoj specifičnoj ljudskoj aktivnosti ${ }^{5}$, protupravnost nije bila posebnim predmetom znanstvenog proučavanja hrvatske pravne književnosti. Komentaristička i udžbenička književnost također tek lapidarno spominju protupravnost te bi se stavove o tom institutu načelno moglo sažeti u ono što je navedeno u prethodnom odjeljku ovog poglavlja.

Pri takvom stanju stvari niz je teorijski, ali i praktično zanimljivih pitanja vezanih uz protupravnost otvoreno kao što su, primjerice, pitanje je li protupravnost u objektivnom smislu uopće pretpostavka odgovornosti za štetu, što protupravnost u objektivnom smislu zapravo znači, odnosno u kojoj su mjeri izvanzakonski, autonomni izvori prava relevantni u pogledu utvrđivanja protupravnosti, odnosi li se protupravnost u objektivnom smislu isključivo na

1 Klarić, P.; Vedriš, M., Građansko pravo, Narodne novine, Zagreb, 2014., str. 583 584; Crnić, I., Zakon o obveznim odnosima, Organizator, Zagreb, 2006., str. 702 - 705; Baretić, M., Tort Law, u: Josipović, T. (ur.), Introduction to the Law of Croatia, Wolters Kluwer, Alphen aan den Rijn, 2014., str. 169 - 170; Gorenc, V. et al., Komentar Zakona o obveznim odnosima, RRiF, Zagreb, 2005., str. $1604-1610$.

2 Klarić; Vedriš, op. cit. u bilj. 1, str. 597.

3 Klarić; Vedriš, op. cit. u bilj. 1, str. 584.

4 Stipković, Z., Protupravnost kao pretpostavka odgovornosti za štetu, Pravni fakultet Sveučilišta u Zagrebu, Zagreb, 1991.

5 Gliha, I., Protupravnost kao pretpostavka odgovornosti za štetu nastalu u športu, Privreda i pravo, vol. 32, 1993. 
štetnu radnju ili su mogući slučajevi u kojima će se protupravnost odnositi na rezultat štetne radnje.

Nadalje, hrvatska pravna književnost ne nudi odgovor na pitanje utječu li pojedini elementi konkretnog slučaja, poput primjerice narav zaštićenog dobra, opasnost štetne radnje, predvidljivost štete, dostupnost alternativnih metoda zaštite ugroženih dobara, na postojanje protupravnosti u objektivnom smislu.

Osim navedenih, interesantno bi bilo promotriti i pitanje je li jasno razlikovanje objektivnog i subjektivnog elementa protupravnosti uvijek moguće ili je u određenim slučajevima granicu između tih dvaju elemenata protupravnosti nemoguće nedvosmisleno utvrditi te pitanje o kojim je elementima potrebno voditi računa prilikom utvrđivanja protupravnosti, odnosno mogu li neki subjektivni elementi, poput, dobi, psihičkog ili fizičkog stanja, iskustva i ostalih subjektivnih karakteristika, utjecati na utvrđivanje protupravnosti u konkretnom slučaju.

Niz pitanja vezanih uz protupravnost na koje hrvatska pravna književnost ne daje adekvatne odgovore opravdava nešto dublju analitičku obradu toga instituta. Pritom, budući da, kao što je već rečeno, hrvatska pravna književnost protupravnosti nije pridavala veću pozornost, u pronalaženju odgovora na ovdje postavljena pitanja oslonit ćemo se sudsku praksu. Stoga će u ovom radu biti analizirano na koji način sudska praksa u Hrvatskoj percipira protupravnost, kako je tumači i kako primjenjuje. Može se očekivati da će takav pristup omogućiti pronalaženje odgovora na neka od ovdje postavljenih pitanja.

\section{PROTUPRAVNOST KAO PRETPOSTAVKA ODGOVORNOSTI ZA ŠTETU}

\subsection{Je li protupravnost uopće pretpostavka odgovornosti za štetu?}

Kao što je već navedeno, u hrvatskoj se pravnoj književnosti protupravnost beziznimno smatra pretpostavkom odgovornosti za štetu. No Zakon o obveznim odnosima $^{6}$, koji predstavlja temeljni, opći propis hrvatskog obveznopravnog poretka, nigdje izrijekom ne spominje protupravnost kao pretpostavku odgovornosti za štetu. Legitimno je, stoga, postaviti pitanje je li u hrvatskom odštetnom pravu protupravnost uopće pretpostavka odgovornosti za štetu.

Opravdanost dovođenja u pitanje protupravnosti kao pretpostavke odgovornosti za štetu mogla bi se potkrijepiti s nekoliko argumenata.

6 Zakon o obveznim odnosima, Narodne novine, br. 35/2005, 41/2008, 78/2015, $29 / 2018$. 
Prvo, usporednopravna analiza sugerira kako je u mnogim pravnim porecima protupravnost izrijekom navedena kao pretpostavka odgovornosti za štetu. Tako je, primjerice, paragrafom 823. stavkom 1. njemačkog BGB-a određeno da će za štetu odgovarati onaj tko protupravno povrijedi tuđi život, tijelo, zdravlje, slobodu, imovinu ili neko drugo pravo. ${ }^{7} \mathrm{Na}$ gotovo identičan način protupravnosti pristupa austrijski ABGB, koji paragrafom 1294. određuje da šteta proizlazi iz nekog protupravnog djelovanja, odnosno propuštanja ili iz slučaja ${ }^{8}$, švicarski OR, koji člankom 41. propisuje da tko drugome protupravno nanese štetu, namjerno ili nepažnjom, dužan ju je naknaditi', te talijanski Codice Civile, koji u članku 2043. propisuje da svaki čin, namjerni ili nepažljiv, koji drugome prouzroči protupravnu štetu, obvezuje onoga tko ga je poduzeo da naknadi time prouzročenu štetu. ${ }^{10}$

S druge strane, francuski Code civil, na koji se naše odštetnopravno uređenje značajno naslanja, izričito ne spominje protupravnost kao pretpostavku odgovornosti za štetu, već samo u članku 1240. navodi da bilo koji čin čovjeka koji drugome prouzroči štetu obvezuje onoga čijom je krivnjom nastao da je popravi. ${ }^{11}$

7 Paragraf 823., stavak 1. njemačkog BGB-a glasi:

“(1) Wer vorsätzlich oder fahrlässig das Leben, den Körper, die Gesundheit, die Freiheit, das Eigentum oder ein sonstiges Recht eines anderen widerrechtlich verletzt, ist dem anderen zum Ersatz des daraus entstehenden Schadens verpflichtet."

8 Paragraf 1294. austrijskog ABGB-a glasi:

"Quellen der Beschädigung

Der Schade entspringt entweder aus einer widerrechtlichen Handlung, oder Unterlassung eines Anderen; oder aus einem Zufalle. Die widerrechtliche Beschädigung wird entweder willkührlich, oder unwillkührlich zugefügt. Die willkührliche Beschädigung aber gründet sich theils in einer bösen Absicht, wenn der Schade mit Wissen und Willen; theils in einem Versehen, wenn er aus schuldbarer Unwissenheit, oder aus Mangel der gehörigen Aufmerksamkeit, oder des gehörigen Fleißes verursachet worden ist. Beydes wird ein Verschulden genannt."

9 Članak 41. švicarskog OR-a glasi:

"A. Haftung im Allgemeinen

I. Voraussetzungen der Haftung

1. Wer einem andern widerrechtlich Schaden zufügt, sei es mit Absicht, sei es aus Fahrlässigkeit, wird ihm zum Ersatze verpflichtet.

2. Ebenso ist zum Ersatze verpflichtet, wer einem andern in einer gegen die guten Sitten verstossenden Weise absichtlich Schaden zufügt."

10 Članak 2043. Codice Civilea glasi:

"(Risarcimento per fatto illecito) - Qualunque fatto doloso o colposo, che cagiona ad altri un dano ingiusto, obbliga colui che ha commesso il fatto a risarciare il danno."

11 Članak 1240 Code civila glasi:

“Tout fait quelconque de l'homme, qui cause à autrui un dommage, oblige celui par la faute duquel il est arrivé, à le réparer." 
Moglo bi se, stoga, rezonirati da oni poreci koji žele propisati protupravnost kao pretpostavku odgovornosti za štetu čine to izričito. Može se, dakle, postaviti pitanje, je li moguće da francusko, a po uzoru na njega i hrvatsko pravo, uopće ne predviđaju protupravnost kao pretpostavku odgovornosti za štetu.

Nadalje, činjenica je da hrvatski pravni poredak izrijekom propisuje dužnost uzdržavanja od prouzročenja štete. ${ }^{12}$ To takozvano neminem laedere načelo, koje je izrijekom predviđeno samo u rijetkim pravnim porecima, u svojoj biti predstavlja negaciju protupravnosti kao posebne pretpostavke odgovornosti za štetu jer se svakim nanošenjem štete ujedno povrjeđuje to pravno pravilo pa time svaki slučaj nanošenja štete a priori postaje protupravan, bez obzira na to je li svojom radnjom kojom je prouzročio štetu štetnik povrijedio bilo koje drugo pravno pravilo, odnosno općenito bez obzira na to može li se štetniku, bilo objektivno ili subjektivno, išta prigovoriti u pogledu njegova postupanja. ${ }^{13}$ Dapače, u hrvatskoj pravnoj književnosti ${ }^{14}$, ali i u pravnoj književnosti ostalih pravnih poredaka koji baštine tradiciju ZOO-a ${ }^{15}$, moguće je naići na stav da i dužnost suzdržavanja od prouzročenja štete predstavlja pravno pravilo objektivnog prava čija će povreda dovesti do nastanka odnosa odgovornosti za štetu. U tom smislu moglo bi se rezonirati da izričito zakonsko propisivanje dužnosti uzdržavanja od štete čini protupravnost nepotrebnom jer će svako nanošenje štete a priori biti protupravno.

Konačno, neki posebni propisi, kojima se uređuje odgovornost za štetu u nekim posebnim slučajevima, ponekad izrijekom navode protupravnost kao pretpostavku odgovornosti za štetu. Tako je, primjerice, člankom 165. Zakona o rudarstvu ${ }^{16}$ protupravnost izrijekom propisana kao pretpostavka odgovornosti za štetu prouzročenu izvođenjem rudarskih radova bez pravne osnove. Takav normativni okvir mogao bi sugerirati kako je, u onim slučajevima u kojima je

12 Vidi čl. 8. ZOO-a koji glasi:

"Svatko je dužan uzdržati se od postupka kojim se može drugome prouzročiti šteta."

13 Vidi Stipković, op. cit. u bilj. 4, str. 84; Gliha, I.; Baretić, M.; Nikšić, S., Pure Economic Loss in Croatian Law, u: Bussani, M. (ur.), European Tort Law, Eastern and Western Perspectives, Stämpfli, Ant. N. Sakkoulas, Sellier, Bruylant, Bern, Brussels, Athens, 2007., str. 256.

14 Vidi, primjerice, Crnić, op. cit. u bilj. 1, str. 705; Gorenc, op. cit. u bilj. 1, str. 1610.

15 Vidi, primjerice, Galev, G.; Dabović-Anastasovska, J., Obligaciono pravo, Univerzitet "Sv. Kiril i Metodij", Skopje, Praven fakultet "Iustinijan Prvi", Skopje, 2012., str. 622 - 623; Bikić, A., Naknada štete, Pravni fakultet Sarajevo, Sarajevo, 2010., str. 17; Antić, O., Obligaciono pravo, Službeni glasnik, Beograd, 2009., str. 470 - 475.

16 Zakon o rudarstvu, Narodne novine, br. 56/2013, 14/2014, 52/2018, 115/2018, 98/2019. 
smatrao potrebnim propisati da protupravnost jest pretpostavka odgovornosti za štetu, hrvatski zakonodavac to izrijekom učinio. To bi, argumentum a contrario, moglo nadalje sugerirati kako u onim situacijama u kojima to nije izrijekom zakonski predviđeno protupravnost ne predstavlja pretpostavku odgovornosti za štetu.

Unatoč gore navedenim argumentima više je argumenata koji govore u prilog tvrdnji da protupravnost jest posebna pretpostavka odštetnopravne odgovornosti u hrvatskom pravu.

Prije svega, nije sasvim točno da francusko pravo ne predviđa protupravnost kao pretpostavku odgovornosti za štetu. Naime, članak 1382. Code civila govori o odgovornosti za štetu prouzročenu skrivljenim ponašanjem. Pritom valja naglasiti da se francuski pojam faute, slobodno preveden kao krivnja, sadržajno značajno razlikuje od hrvatskog instituta krivnje. Naime, dok se u hrvatskom pravu, kao što je već prikazano, krivnja većinski smatra isključivo subjektivnim elementom protupravnosti, u francuskom pravu institut faute složeni je institut koji u sebi sadržava i subjektivne i objektivne elemente. U tom smislu, kada francuski Code civil propisuje da se odgovara za svaku skrivljenu štetu, podrazumijeva se da će se odgovarati za svaku štetu koja je rezultat radnje kojom se povrjeđuje neko pravno pravilo, pravo, dužnosti ili obveza, dakle za svaku štetu koja je protupravna. ${ }^{17}$ Francusko pravo stoga također poznaje koncept protupravnosti, doduše ne kao samostalnu pretpostavku odgovornosti za štetu, već kao konstitutivni element složenog pojma faute (krivnja). ${ }^{18} \mathrm{U}$ tom smislu, prihvatimo li tezu da je hrvatski odštetnopravni sustav, predviđen ZOO-om, uglavnom utemeljen na francuskom pravu, ujedno moramo prihvatiti da je i u našem pravu, jednako kao i u francuskom, za nastanak odnosa odgovornosti za štetu potrebna, među ostalim, i protupravnost.

Stoga, bez obzira na to predviđa li je izrijekom određeni propis kao pretpostavku odgovornosti za štetu ili ne predviđa, protupravnost jest inherentna našem odštetnopravnom sustavu. Takav se stav, uostalom, može potkrijepiti referencom na našu sudsku praksu koja je u mnogim slučajevima izrijekom ustvrdila da je protupravnost jedna od općih pretpostavka odgovornosti za štetu.

17 Isto, Stipković, op. cit. u bilj. 4, str. $44-45$.

18 Svi nacionalni pravni poreci koji baštine tradiciju ZOO-a iz 1978. godine također su utemeljeni na francuskoj matrici. Zbog toga se vjerojatno u srpskoj pravnoj književnosti o protupravnosti ne govori kao posebnoj pretpostavci odgovornosti za štetu, već kao konstitutivnom elementu krivnje, baš kao što je to slučaj u francuskom pravu. (Vidi Antić, op. cit. u bilj. 15, str. 467 - 471). 
Tako je, primjerice, u presudi br. Rev-x 544/2012-2 od 19. rujna 2012. godine ${ }^{19}$ Vrhovni sud Republike Hrvatske (dalje u tekstu: VSRH) ustvrdio da su opće pretpostavke izvanugovorne odgovornosti za štetu: štetna radnja, šteta, uzročna veza i protupravnost štetne radnje, s time da je štetna radnja protupravna ako je njome povrijeđen pravni propis. Isti je stav u pogledu pretpostavka potrebnih za postanak obveznopravnog odnosa odgovornosti za štetu VSRH izrazio i u presudama Rev 1306/06-2 od 28. veljače 2007. godine ${ }^{20}$, Rev 635/08-2 od 8. rujna 2009. godine ${ }^{21}$, Gzz-39/03-3 od 27. svibnja 2003. godine. ${ }^{22}$ Dapače, u presudi Rev 503/08-2 od 21. svibnja 2008. godine VSRH izražava stav da je protupravnost nužna pretpostavka i kod objektivne odgovornosti za štetu. ${ }^{23}$

U nizu svojih odluka VSRH izrijekom potvrđuje da bez protupravnosti nema odgovornosti za štetu. Tako je, primjerice, u predmetu Rev 1535/1990-2 od 9. siječnja 1991. godine VSRH djelomično ukinuo nižestupanjske presude i predmet vratio nižim sudovima na ponovno odlučivanje ustvrdivši da, dosuđujući tužitelju naknadu štete, nižestupanjski sudovi nisu obrazložili u čemu se sastoji protupravnost tuženikova ponašanja, zaključujući pritom da bez protupravnosti nema ni osnove da tužitelj zahtijeva naknadu štete. ${ }^{24} \mathrm{U}$ već spomenutom predmetu Rev-x 544/2012-2 od 19. rujna 2012. godine VRSH odlučio je kako su odluke nižestupanjskih sudova kojima su odbili tužiteljev zahtjev za naknadu štete pravilne jer u postupku nije dokazano postojanje protupravnosti, pa time nisu ni ispunjene potrebne pretpostavke odgovornosti za štetu. U predmetu Rev 976/2007-2 od 9. siječnja 2008. godine ${ }^{25}$ VSRH potvrđuje nižestupanjske presude kojima je odbijen tužbeni zahtjev za naknadu štete. U tom predmetu tužitelj je zahtijevao naknadu štete koju mu je tuženik navodno prouzročio neosnovanim podnošenjem prijave nadležnom tijelu radi prekomjerne razine

19 Izvor: http://www.iusinfo.hr/CaseLaws/Content.aspx?SOPI=VSRH2012RevxB544 A2\&Doc=VRHSUD_HR (18. listopada 2020.).

20 Izvor: http://www.iusinfo.hr/CaseLaws/Content.aspx?SOPI=VSRH2006RevB1306 A2\&Doc=VRHSUD_HR (18. listopada 2020.).

21 Izvor: http://www.iusinfo.hr/CaseLaws/Content.aspx?SOPI=VSRH2008RevB635A 2\&Doc=VRHSUD_HR (18. listopada 2020.).

22 Izvor: http://www.iusinfo.hr/CaseLaws/Content.aspx?SOPI=VSRH2003GzzB39A3 \&Doc=VRHSUD_HR (18. listopada 2020.).

23 Izvor: http://www.iusinfo.hr/CaseLaws/Content.aspx?SOPI=VSRH2008RevB503A 2\&Doc=VRHSUD_HR (18. listopada 2020.).

24 Izvor: http://www.iusinfo.hr/CaseLaws/Content.aspx?SOPI=VSRH1990RevB1535A 2\&Doc=VRHSUD_HR (18. listopada 2020.).

25 Izvor: http://www.iusinfo.hr/CaseLaws/Content.aspx?SOPI=VSRH2007RevB976A 2\&Doc $=$ VRHSUD_HR (18. listopada 2020.). 
buke. Budući da je tijekom zaustavljanja proizvodnje radi mjerenja buke došlo do oštećenja njegove opreme, tužitelj je, nakon što se pokazalo da razina buke nije prekoračena, podigao protiv tuženika tužbu, smatrajući da mu je svojom neosnovanom prijavom ovaj prouzročio štetu. VSRH potvrdio je nižestupanjske presude kojima je tužbeni zahtjev tužitelja odbijen, zaključujući kako se samo podnošenje prijava i drugih mjera radi zaštite od štetnih imisija ne može smatrati protupravnim, bez obzira na to kako su postupci u povodu tih prijava završeni pa, samim time, nema ni odgovornosti za štetu tuženika. Pritom, VSRH izrazio je stav kako bi o protupravnom djelovanju eventualno bilo riječi u slučajevima kada bi netko zloporabio svoje pravo na podnošenje takvih prijava.

Izričito zakonsko propisivanje načela neminem laedere u hrvatskom pravu također ne može poslužiti kao argument $\mathrm{u}$ prilog tvrdnji da protupravnost $\mathrm{u}$ našem pravnom poretku nije pretpostavka odgovornosti za štetu. Naime, striktno tumačenje toga načela, prema kojem bi ono predstavljalo negaciju protupravnosti kao samostalne pretpostavke odgovornosti za štetu - budući da bi na temelju tog načela svako nanošenje štete bilo a priori protupravno - ne podržava ni hrvatsko zakonodavstvo, ni hrvatska pravna književnost i sudska praksa.

ZOO predviđa niz slučajeva isključenja protupravnosti kao što su nužna obrana, stanje nužde, dopuštena samopomoć i pristanak oštećenika, u kojima, dakle, štetnik neće odgovarati unatoč činjenici da je šteta prouzročena. ${ }^{26}$ Nadalje, ovo striktno tumačenje načela neminem laedere, prema kojem bi svako nanošenje štete bilo a priori protupravno, izrijekom odbacuje i hrvatska pravna književnost, držeći da bi takvo strogo tumačenje toga načela dovelo do potpunog zastoja u svakodnevnom životu jer je relativno mali broj postupanja koja nemaju potencijal prouzročiti štetu drugome. ${ }^{27,28}$ Konačno, ideju da bi svako prouzročenje štete a priori bilo protupravno ne podržava ni hrvatska sudska praksa. Naime, kao što je to moguće zaključiti iz velikog broja slučajeva rješavanih pred hrvatskim sudovima, sama činjenica da je šteta prouzročena nečijom radnjom neće biti dovoljna za nametanje odgovornosti za štetu, već se osim nastale štete posebno

26 Vidi čl. 1052. - 1054. ZOO-a.

27 Vidi Stipković, op. cit. u bilj. 4, str. 64; Gliha; Baretić; Nikšić, op. cit. u bilj. 13, str. 256 - 257; Baretić, op. cit. u bilj. 1, str. 169 - 170.

28 Neki drugi pravni poreci koji izrijekom propisuju načelo neminem laedere, poput primjerice španjolskog, također odbacuju takvo striktno tumačenje toga načela (Vidi Martín-Casals, M.; Ribot, J., Compensation for Pure Economic Loss under Spanish Law, u: van Boom, W. N.; Koziol, H.; Witting, C. A. (ur.), Pure Economic Loss, Springer, Wien, New York, 2004., str. 63 - 65). U srpskom pravu slične stavove izražavaju Blagojević i Krulj (vidi Blagojević, B. T.; Krulj, V., Komentar Zakona o obligacionim odnosima, Savremena administracija, Beograd, 1980., str. 445). 
traži da štetnikova radnja kojom je šteta prouzročena bude ujedno protivna nekom pravnom pravilu.

Tako je, primjerice, u presudi Pn-6472/00 Gžn-2882/07 od 15. rujna 2009. godine Županijski sud u Zagrebu odbio zahtjev oštećenika za naknadu štetu koju je pretrpio zbog zaraze hepatitisom C prilikom transfuzije krvi obavljene od strane štetnika. U konkretnom slučaju, unatoč činjenici da je nesporno utvrđeno kako je tijekom transfuzije obavljene od strane štetnika (bolnice) oštećenik (pacijent) bio zaražen hepatitisom C, Županijski sud u Zagrebu odlučio je da nema odgovornosti štetnika jer je prilikom transfuzije krvi postupao u skladu s tada važećim propisima i pravilima medicinske struke. Tako je tijekom postupka utvrđeno da nije sam štetnik prikupio i obradio zaraženu krv, već da je izvršio transfuziju krvi koju je pribavio od nadležne institucije (Zavoda za transfuzijsku medicinu). Osim toga, Županijski je sud utvrdio da u vrijeme nastanka štetnog događaja nije postojala zakonska obveza kontrole prikupljene krvi na postojanje virusa hepatitisa C. Na temelju takvih utvrđenja taj je sud zaključio kako nije bilo ničeg protupravnog u ponašanju štetnika te je odbio tužiteljev tužbeni zahtjev. Nesporno je, dakle, da je radnjom štetnika (transfuzijom krvi) oštećeniku nanesena šteta (narušenje zdravlja zarazom virusom hepatitisom C). No, budući da štetna radnja (transfuzija krvi) nije ujedno bila i protupravna, sudovi su zaključili kako nema odgovornosti štetnika.

$\mathrm{Na}$ identičan je način VSRH rezonirao u već citiranom predmetu Rev 635/08-2 od 8. rujna 2009. godine. Predmet spora bio je zahtjev jednog trgovačkog društva protiv Republike Hrvatske za naknadu štete prouzročene zbog navodno nezakonitog i nepravilnog rada državnih tijela. Tijekom postupka utvrđeno je da je pravomoćnim rješenjem financijske policije tužitelju bio privremeno zabranjen rad zbog privrednog prijestupa te da je tužitelj naknadno pred nadležnim sudom pravomoćno osuđen za privredni prijestup. U svojoj odluci VSRH uvodno se pozvao na članak 13. Zakona o sustavu državne uprave kojim je propisano da Republika Hrvatska odgovara za štetu koja nastane pravnoj osobi nezakonitim ili nepravilnim radom tijela državne uprave. No, na temelju gore opisanog činjeničnog stanja VSRH zaključio je kako u ovom slučaju nije bilo protupravnosti na strani tužene, odnosno njezinih tijela u postupanju prema tužitelju, jer je tužitelju bio zakonito i osnovano privremeno zabranjen rad te je VSRH potvrdio nižestupanjske presude kojima je tužiteljev tužbeni zahtjev za naknadu štete pretrpljene privremenom zabranom obavljanja djelatnosti bio odbijen kao neosnovan.

Ove odluke jasno pokazuju kako samo prouzrokovanje štete neće biti dovoljno za odgovornost, kao što bi to sugeriralo striktno tumačenje načela neminem laedere. Dakle, suprotno onome što se ponekad zagovara u našoj pravnoj književnosti, 
sama povreda članka 16. ZOO-a, kojim je predviđena dužnost suzdržavanja od prouzročenja štete, neće dovesti do odštetnopravne odgovornosti. Osim toga, bit će potrebno da je štetnikovim postupanjem povrijeđeno neko drugo pravno pravilo koje predstavlja dio pravnog poretka, kojim je adresatima nametnuta neka dužnost ili zabrana. Protupravnost, dakle, nesumnjivo jest jedna od općih pretpostavka građanskopravne odgovornosti za štetu.

\subsection{Odgovornost bez protupravnosti}

U iznimnim, zakonom izrijekom propisanim situacijama do odgovornosti za štetu dolazit će bez protupravnosti na strani odgovorne osobe. Tako je, primjerice, Zakonom o odgovornosti za štetu nastalu uslijed terorističkih akata i javnih demonstracija ${ }^{29}$ predviđeno da će Republika Hrvatska odgovarati za štetu prouzročenu terorističkim aktima i javnim demonstracijama neovisno o tome je li štetnik utvrđen, kažnjeno progonjen ili oglašen krivim. Pritom, kao što je to izrijekom predviđeno u članku 2. toga Zakona te kao što je to u niz predmeta ustvrdio i VSRH, u slučaju šteta prouzročenih terorističkim aktima Republika Hrvatska ne odgovara na temelju svoje protupravnosti, zbog eventualnog propusta u sprječavanju takvih akata, već na temelju načela društvene solidarnosti, ravnomjernog snošenja javnog tereta te pravičnog i brzog obeštećenja. ${ }^{30}$

\subsection{Kumulacija pretpostavka odgovornosti za štetu}

Iz prethodnog izlaganja u ovom poglavlju nesporno je da protupravnost jest opća pretpostavka odgovornosti za štetu te da bez protupravnosti na strani štetnika ne može doći do odštetnopravne odgovornosti, osim u onim iznimnim slučajevima u kojima, kao što je to gore prikazano ${ }^{31}$, zakon izrijekom predviđa odgovornost bez protupravnosti. No, isto tako potrebno je naglasiti da je protupravnost tek jedna od potrebnih pretpostavka te da će, kako je to u predmetu Rev 635/08-2 ustvrdio VSRH, do odgovornosti za štetu doći jedino ako su kumulativno ispunjene sve zakonom propisane pretpostavke odgovornosti za štetu.

29 Zakon o odgovornosti za štetu nastalu uslijed terorističkih akata i javnih demonstracija, Narodne novine, br. 117/2003.

30 Vidi, primjerice, presudu u predmetu Rev 1248/07-2 od 30. siječnja 2008. godine. Izvor: http://www.iusinfo.hr/CaseLaws/Content.aspx?SOPI=VSRH2007RevB1248 A2\&Doc=VRHSUD_HR (18. listopada 2020.).

31 Vidi supra 2.2. 
U tom smislu, čak ako u konkretnom slučaju postupanje određene osobe jest bilo protupravno, to neće nužno voditi do njezine odštetnopravne odgovornosti ako pritom nisu kumulativno ispunjene i ostale pretpostavke odgovornosti za štetu. U pravnoj se književnosti, u tom pogledu, često navodi kako protupravno postupanje, primjerice počinjenje nekog kaznenog djela, prekršaja i sl., neće dovesti do odštetnopravne odgovornosti ako takvim postupanjem nije ujedno došlo do prouzročenja štete $\mathrm{u}$ građanskopravnom smislu. ${ }^{32}$ Hrvatska sudska praksa također upućuje na to kako su relativno česti slučajevi u kojima, iako je došlo do protupravnog postupanja i do nastupanja određene štete, ne dolazi do nastupanja odštetnopravne odgovornosti, ako nisu ispunjene i ostale pretpostavke odgovornosti, primjerice, ako ne postoji uzročna veza.

Tako je, primjerice, u slučaju Gž-2584/14-2 od 5. listopada 2015. godine ${ }^{33}$ Županijski sud u Varaždinu zaključio da sama protupravnost nečijeg postupanja nije dovoljna za nastanak odgovornosti za štetu ako između te protupravnosti i nastale štete nema uzročne veze. Slučaj se odnosio na tužbeni zahtjev oštećenice koja je bila ozlijeđena kada je u rekreacijskom parku na nju naletio biciklist. Oštećenica podiže tužbeni zahtjev protiv osiguratelja gradske tvrtke zadužene za održavanje rekreacijskog parka, držeći je odgovornom za štetu jer je prometna infrastruktura u parku navodno bila nepravilno izvedena te jer rekreacijski park nije dobio uporabnu dozvolu prije otvaranja za građanstvo. Prvostupanjski je sud odbio tužbeni zahtjev, a Županijski sud u Varaždinu, djelujući kao drugostupanjski sud, potvrdio prvostupanjsku presudu u tom dijelu. U obrazloženju svoje odluke Županijski je sud u Varaždinu ustvrdio da je prometna signalizacija koja razdvaja biciklističku od pješačke staze izvedena u skladu s relevantnim propisima te da s te strane nema protupravnosti u ponašanju tuženika. Što se tiče činjenice da za rekreacijski park nikad nije ishođena uporabna dozvola, Županijski je sud u Varaždinu utvrdio kako tužiteljica nije uspjela dokazati da bi neizdavanje uporabne dozvole bilo u uzročnoj vezi s nastalom štetom.

U ovom slučaju svakako treba pozdraviti vrlo suptilan pristup Županijskog suda u Varaždinu problemu protupravnosti. Naime, mjerodavni propisi o građenju nalažu da svaka građevina mora imati uporabnu dozvolu prije nego što ju se počne uporabljati za svrhe za koje je namijenjena. U tom smislu, otvaranjem rekreacijskog parka za građanstvo prije negoli je ishođena uporabna dozvola, tvrtka koja upravlja tim parkom svakako jest postupila protivno važećim propisima. No, Županijski je sud u Varaždinu očito vodio računa o tome da se

32 Gorenc, op. cit. u bilj. 1, str. 1610; Galev; Dabović-Anastasovska, op. cit. u bilj. 15, str. 624; Bikić, op. cit. u bilj. 15, str. 16.

33 Vidi detaljnije o slučaju: Baretić, M., Croatia, u: Karner, E.; Steininger, B. (ur.), European Tort Law 2015, de Gruyter, Berlin, Boston, 2016., str. 83 - 86. 
uporabnom dozvolom ne potvrđuje samo usklađenost građevinskog objekta sa sigurnosnim zahtjevima, već i sa svim ostalim građevinskim zahtjevima koji nisu nužno vezani uz sigurnost objekta te da, u tom smislu, nepostojanje uporabne dozvole ne znači nužno da objekt ne ispunjava sigurnosne zahtjeve. Na temelju takvih utvrđenja Županijski je sud u Varaždinu donio očito opravdan zaključak kako tužiteljica ničim nije dokazala da bi šteta koja joj je nastala bila prouzročena propustom tuženika da ishodi uporabnu dozvolu za objekt u kojem je tužiteljica pretrpjela štetu, dakle da između tuženikova protupravnog ponašanja i tužiteljeve štete nema uzročne veze.

\section{PROTUPRAVNOST KAO PROTIVNOST OBJEKTIVNOM PRAVU}

U pravnoj se književnosti nailazi na stavove da protupravnost u objektivnom smislu znači povredu nekog pravnog pravila pozitivnog pravnog poretka ${ }^{34}$, povredu pravnog propisa ${ }^{35}$, odnosno povredu pravne norme. ${ }^{36}$ No, hrvatska pravna književnost ne eksplicira na što se zapravo misli pod "pravilima pozitivnog pravnog poretka", "pravnim propisom" i "pravnom normom". Ostaje, stoga, otvoreno pitanje jesu li tim terminima obuhvaćene samo zakonske norme ili i ostala pravila ponašanja koja nisu nužno inkorporirana u zakone.

Neki autori izrijekom navode da se o protupravnosti može govoriti jedino u slučaju povrede zakonskih propisa. ${ }^{37}$ Drugi pak impliciraju da protupravnost $\mathrm{u}$ pravilu podrazumijeva povredu zakonskih imperativnih propisa, iako dopuštaju mogućnost da ona bude rezultat povrede nekog običaja, odnosno moralnog pravila. $^{38}$

Hrvatska sudska praksa sugerira kako pojam protupravnosti obuhvaća vrlo širok spektar zakonskih i izvanzakonskih pravila postupanja.

Pod protupravnošću u hrvatskoj se sudskoj praksi ponajprije misli na protivnost štetnikova ponašanja nekom zakonskom pravilu. Tako je, primjerice, $u$ već citiranoj presudi Rev-x 544/2012-2 VSRH zaključio kako je štetna radnja protupravna ako je njome povrijeđen pravni propis. Na sličan je način VSRH rezonirao u predmetu Rev 713/98 od 13. rujna 2000. godine, kada je ustvrdio

34 Vidi Klarić; Vedriš, op. cit. u bilj. 1, str. 596.

35 Vidi Crnić, op. cit. u bilj. 1, str. 705.

36 Gorenc, op. cit. u bilj. 1, str. 1610.

37 Vidi Bikić, op. cit. u bilj. 15, str. 16.

38 Vidi Galev; Dabović-Anastasovska, op. cit. u bilj. 15, str. 622. 
da je određeno propuštanje ili postupanje protupravno ako je suprotno zakonu, drugom propisu ili općem aktu. ${ }^{39}$

Naravno, o postojanju protupravnosti u prvom će se redu odlučivati na temelju pravila obveznog, odnosno šire, građanskog prava. Tako je, primjerice, u već citiranoj presudi Rev 976/2007-240 VSRH potvrdio da bi bilo riječi o protupravnom ponašanju ako bi štetnik zlorabio neko svoje pravo, dakle ako bi postupao suprotno zabrani zloporabe prava, kao jednog od temeljnih načela našeg obveznopravnog poretka predviđenog člankom 6. ZOO-a. U književnosti se također zastupa stav da bi i povreda drugih temeljnih načela obveznog prava, poput, primjerice, načela savjesnosti i poštenja, također predstavljala protupravno ponašanje. ${ }^{41}$ No, pritom bi trebalo voditi računa da, na temelju članka 4. ZOO-a, u hrvatskom pravnom poretku načelo savjesnosti i poštenja obvezuje strane isključivo prilikom zasnivanja obveznih odnosa i prilikom ostvarivanja prava i obveza iz tih odnosa. U tom smislu povreda načela savjesnosti i poštenja mogla bi se smatrati protupravnim ponašanjem jedino ako je došlo do povrede već postojećeg obveznopravnog odnosa, bilo ugovornog bilo predugovornog. Osim kod povrede općih načela obveznog, odnosno građanskog prava, o protupravnosti bi bilo riječi i kod povrede bilo koje druge imperativne norme zakona kojima se uređuju građanskopravni odnosi. ${ }^{42}$

Kao što se to navodi u pravnoj književnosti ${ }^{43}$ te kao što to potvrđuje i hrvatska sudska praksa, da bi došlo do protupravnosti, ne mora nužno biti riječ o povredi pravila iz domene građanskog prava, već će i povreda propisa iz drugih grana prava, poput kaznenog, prekršajnog, upravnog prava i sl., dovoditi do protupravnosti štetnikova ponašanja. Tako je, primjerice, u presudi Rev 635/08-2 VSRH prosuđivao o protupravnosti tuženikova postupanja s obzirom na zahtjeve iz Zakona o sustavu državne uprave, dakle propisa iz domene upravnog prava. U već citiranoj presudi Pn 1995/85 Gž-13/8844 sudovi su prosuđivali o postojanju, odnosno nepostojanju protupravnosti na temelju zakonskih propisa kojima se uređuje sigurnost cestovnog prometa. U presudi Rev 735/05-245 sud je prosuđivao protupravnost tuženikova ponašanja, među ostalim, na temelju zakonskih pravila kojima je uređen promet željeznicom, dok

\footnotetext{
Citirano prema Gorenc, op. cit. u bilj. 1, str. 1611.

40 Vidi supra 2.1.

41 Vidi Galev; Dabović-Anastasovska, op. cit. u bilj. 15, str. 623.

42 Vidi Galev; Dabović-Anastasovska, op. cit. u bilj. 15, str. 623.

43 Vidi Galev; Dabović-Anastasovska, op. cit. u bilj. 15, str. 623.

44 Vidi supra t. 2.3.

45 Vidi infra 5.
} 
je u presudi Pn-6472/00 Gžn-2882/07 o postojanju protupravnosti odlučeno na temelju zakonskih pravila kojima se uređuje zdravstvena djelatnost. U presudi Rev-x 32/2010-2 od 27. listopada 2010. godine o protupravnosti je odlučivano na temelju Zakona o lovu. ${ }^{46}$

Bez ikakve sumnje, u imperativne propise po kojima bi trebalo prosuđivati primjerenost štetnikova postupanja svakako pripadaju i Ustav Republike Hrvatske (dalje u tekstu: Ustav) ${ }^{47}$ te međunarodne konvencije koje obvezuju Republiku Hrvatsku. U tom smislu načelno bi i povreda neke norme Ustava ili određene međunarodne konvencije također dovodila do protupravnosti. Tako je, primjerice, u predmetu Gzp 1014/09-3 od 16. veljače 2010. godine VSRH naložio Republici Hrvatskoj naknadu štete prouzročene neosnovano dugim trajanjem parničnog postupka čime su, po ocjeni VSRH-a, povrijeđene relevantne odredbe Ustava i Konvencije za zaštitu ljudskih prava i temeljnih sloboda kojima se građanima jamči pravo na suđenje u razumnom roku. ${ }^{48}$ Ono što je u tom pogledu posebno zanimljivo jest da prilikom ocjene je li ponašanje štetnika usklađeno sa zahtjevima pravnog poretka hrvatski sudovi posebno vode računa o tome je li štetnom radnjom povrijeđeno neko subjektivno pravo koje je zaštićeno Ustavom ili međunarodnom konvencijom, odnosno involvira li štetni događaj na neki drugi način Ustavom ili međunarodnim konvencijama zaštićena prava te da pritom, kao što će to u nastavku biti detaljnije elaborirano $^{49}$, prosuđuju o postojanju odnosno nepostojanju protupravnosti uglavnom kroz prizmu ustavnopravnog značaja prava o kojem je riječ.

Osim na temelju ustavnih, konvencijskih i zakonskih normi protupravnost se često prosuđuje na temelju drugih propisa i općih pravnih akata. Tako je, primjerice, u presudi Rev 1143/2004-2 od 4. siječnja 2006. godine VSRH o protupravnosti tužitelja odlučivao na temelju podzakonskog akta. ${ }^{50}$ Naime, predmet se odnosio na odštetnopravni zahtjev koji je tužitelj podnio protiv tuženika komunalnog poduzeća zbog štete nastale poplavljivanjem tužiteljeva zemljišta. Tijekom čišćenja odvodnog kanala u okviru mjera obrane od poplave tuženik je, radi sprječavanja izlijevanja vode po naseljenom mjestu, bagerom uklonio

46 Izvor: http://www.iusinfo.hr/CaseLaws/Content.aspx?SOPI=VSRH2010RevxB32A 2\&Doc=VRHSUD_HR (19. listopada 2020.).

47 Ustav Republike Hrvatske, narodne novine, br. 56/1990, 135/1997, 8/1998, 113/2000, 124/2000, 28/2001, 41/2001, 55/2001, 76/2010, 85/2010, 05/2014.

48 Izvor: http://www.iusinfo.com.hr/CaseLaws/Content.aspx?SOPI=VSRH2009GzpB 1014A3\&Doc=VRHSUD_HR (19. listopada 2020.).

49 Vidi infra 6.1.

50 Izvor: http://www.iusinfo.hr/CaseLaws/Content.aspx?SOPI=VSRH2004RevB1 143 A2\&Doc=VRHSUD_HR (19. listopada 2020.). 
određenu prepreku na odteretnom kanalu, zbog čega je došlo do poplavljivanja tužiteljeva zemljišta. Odbijajući tužbeni zahtjev, nižestupanjski su sudovi, među ostalim, zaključili kako ponašanje tuženika nije bilo protupravno jer je sporne radnje poduzeo na temelju i u skladu s Planom za obranu od poplava na unutrašnjim vodotocima na području Županije osječko-baranjske. U predmetu Rev 92/2008-2 od 10. rujna 2009. godine o protupravnosti štetnikova postupanja odlučivalo se pak na temelju Odluke o načinu plaćanja komunalnih usluga, općem podzakonskom aktu donesenom na temelju Zakona o komunalnom gospodarstvu. ${ }^{51}$

Dapače, o postojanju, odnosno nepostojanju protupravnosti u hrvatskoj se sudskoj praksi prosuđuje i na temelju pojedinačnih akata. Tako se, primjerice, u presudi Rev 242/2003-2 od 4. lipnja 2003. godine o postojanju protupravnosti odlučivalo na temelju upravnog Rješenja Ministarstva gospodarstva o davanju koncesije za izvođenje rudarskih radova. Tužitelj vlasnik zemljišta tužio je tuženika koncesionara za štetu koju je pretrpio na zemljištu zbog izvođenja eksploatacijskih radova. Nižestupanjski su sudovi odbili tužbeni zahtjev, obrazlažući tu odluku stavom da je tuženik obavljao eksploatacijske radove na temelju valjano izdanog rješenja nadležnog ministarstva, očito implicirajući da zbog toga u postupanju tuženika nije bilo ništa protupravno. VSRH vraća predmet na ponovno odlučivanje nižestupanjskim sudovima, obrazlažući tu odluku stavom da nižestupanjski sudovi nisu provjerili je li tuženik postupio u skladu s odredbom rješenja nadležnog ministarstva kojom je koncesionaru naloženo da riješi imovinskopravne odnose s vlasnikom zemljišta, izražavajući pritom stav da bi se ponašanje tužitelja trebalo smatrati protupravnim ako bi se utvrdilo da nije postupio po navedenoj odredbi rješenja. ${ }^{52}$

Hrvatska sudska praksa, nadalje, sasvim jasno upućuje na to kako će o postojanju protupravnosti u objektivnom smislu biti riječi i u onim slučajevima u kojima je postupanjem štetnika povrijeđeno neko izvanzakonsko, autonomno pravilo postupanja, pisano ili nepisano, kao što su, primjerice, interna pravila pojedinog trgovačkog društva, pravila crkvenog reda, sportska pravila, pravila određene struke itd.

Tako je, primjerice, u slučaju Rev 735/05-2 sud zaključio kako je željeznički operator djelomično odgovoran za štetu koja je prouzročena djetetu koje je, igrajući se na parkiranom željezničkom vagonu, ozlijeđeno strujnim udarom

51 Izvor: http://www.iusinfo.hr/CaseLaws/Content.aspx?SOPI=VSRH2008RevB92A2 $\&$ Doc $=$ VRHSUD_HR (19. listopada 2020.).

52 Izvor: http://www.iusinfo.hr/CaseLaws/Content.aspx?SOPI=VSRH2003RevB242A $2 \&$ Doc $=$ VRHSUD_HR(19. listopada 2020.). 
uslijed kontakta s električnim vodom pod naponom, zbog toga što nije učinio sve što je propisano mjerodavnim zakonom (Zakonom o sigurnosti u željezničkom prometu) i njegovim internim pravilima (Pravilnikom o željezničkom redu) da spriječi pristup neovlaštenih osoba željezničkoj infrastrukturi.

U presudi Rev 917/1990-2 od 12. rujna 1990. godine ${ }^{53}$ VSRH je prosuđivao protupravnost štetnikova postupanja na temelju internih pravila crkvenoga reda. Slučaj se odnosio na bivšu časnu sestru koja je tužila Katoličku crkvu u Hrvatskoj i crkveni red Družbu sestara Srca Isusova za naknadu neimovinske štete koju je navodno pretrpjela zbog neosnovanog otpusta iz crkvenog reda. VRSH je potvrdio presudu nižestupanjskih sudova koji su utvrdili da u postupanju tuženih nije bilo protupravnosti jer je tužiteljica otpuštena iz crkvenog reda u skladu s Pravilima Družbe sestara Srca Isusova.

U presudi Pn-7434/05 Gžn-1606/11 od 19. srpnja 2011. godine Županijski sud u Zagrebu osudio je tuženika na naknadu štete zbog postupanja koje je bilo protivno Pravilniku o nogometnim natjecanjima Hrvatskog nogometnog saveza i Propozicijama natjecanja za prvenstvo 1., 2. i 3. lige Zagreba, izdane od strane Zagrebačkog nogometnog saveza. Oštećenik je bio nogometni sudac na niželigaškim nogometnim natjecanjima koji je ozlijeđen kada je na nogometnoj utakmici napadnut od strane igrača gostujuće momčadi. Sudovi su zaključili kako tuženi organizator nogometne utakmice nije učinio sve što je bilo predviđeno rečenim internim pravilima Hrvatskog nogometnog saveza i Zagrebačkog nogometnog saveza kako bi se spriječili neredi na utakmici.

U presudi Rev-1194/90 od 2. listopada 1990. godine VSRH zauzeo je stav da bi nogometni igrač mogao odgovarati drugom igraču za štetu koju mu je za vrijeme nogometne igre nanio grubim kršenjem nogometnih pravila. ${ }^{54}$

U presudi Pn-6472/00 Gžn-2882/07 Županijski sud u Zagrebu prosuđivao je primjerenost postupanja bolnice kao tuženika ne samo na temelju zakona kojima se uređuje medicinska djelatnost, već i na temelju pravila medicinske struke. Slučaj se, kao što je već navedeno, odnosio na pacijenta koji je tijekom operacije zaražen virusom hepatitisa C. Budući da je sud utvrdio kako u vrijeme nastupanja štetnog događaja mjerodavni propisi i pravila medicinske struke nisu nalagala kontrolu krvi na prisutnost virusa hepatitisa C, Županijski je sud u Zagrebu zaključio kako je tužena bolnica postupala u svemu u skladu s tada važećim propisima i pravilima medicinske struke. $\mathrm{Na}$ isti su način postupili sudovi u predmetu Rev 1671/1990-2 od 13. prosinca 1990. godine, kada su

53 Izvor: http://www.iusinfo.hr/CaseLaws/Content.aspx?SOPI=VSRH1990RevB917A 2\&Doc=VRHSUD_HR (19. listopada 2020.).

54 Citirano prema Gorenc, op. cit. u bilj. 1, str. 1611. 
zaključili da je tuženik odgovoran za štetu prouzročenu uginućem tužiteljeve krave jer prilikom osjemenjivanja životinje nije postupio u skladu s pravilima veterinarske struke..$^{55}$

Konačno, u određenim će se slučajevima o protupravnosti govoriti i zbog povrede obveza preuzetih ugovorom. Tako je u presudi Rev-x 103/08-2 od 17. prosinca 2008. godine VSRH ukinuo nižestupanjske presude i vratio predmet nižestupanjskim sudovima na ponovno odlučivanje. Predmet postupka bio je zahtjev za naknadu štete tužitelja vlasnika nekretnine protiv tuženika posjednika nekretnine prouzročene rušenjem kuće. U sudskom je postupku bilo utvrđeno da su tužitelj i tuženik u okviru upravnog postupka deeksproprijacije sklopili upravnu nagodbu kojom se tuženik obvezao u roku od šest godina srušiti kuću ili, ako to ne učini u tom roku, vratiti posjed kuće tužitelju. Budući da tuženik nije u navedenom roku srušio kuću, tužitelj ga je, na temelju sklopljene nagodbe, tužio zatraživši predaju kuće u posjed. Tijekom postupka tuženik je srušio kuću zbog čega je tužitelj preinačio tužbeni zahtjev i zatražio naknadu štete. Nižestupanjski su sudovi odbili zahtjev obrazlažući tu odluku stavom da je tuženik postupio u skladu sa sklopljenom nagodbom, dakle da u njegovu postupanju nije bilo protupravnosti. VSRH otklanja takvo tumačenje te zaključuje da tuženik nije postupio u skladu s nagodbom, dakle da je djelovao protupravno. ${ }^{56}$

\section{OBJEKT PROTUPRAVNOSTI}

Jedno od teorijski zanimljivih pitanja vezanih uz protupravnost jest pitanje objekta protupravnosti, odnosno pitanje na što se protupravnost zapravo odnosi. Poredbena građanskopravna književnost sugerira kako objekt protupravnosti može biti dvojak: protupravnost se može odnosi na štetnu radnju, odnosno na ponašanje štetnika ili pak na posljedicu određene radnje štetnika. U slučaju protupravnosti koja se odnosi na štetnu radnju (Verhaltensunrecht) smatra se da je određena osoba postupala protupravno ako se utvrdi da je svojim postupanjem povrijedila određenu dužnost. Na temelju učenja o protupravnosti posljedice (Erfolgsunrecht) smatra se da je određena osoba postupala protupravno ako je njezinim postupanjem došlo do neke nedopuštene, protupravne posljedice. ${ }^{57}$

55 Izvor: http://www.iusinfo.com.hr/CaseLaws/Content.aspx?SOPI=VSRH1990RevB1 671A2\&Doc=VRHSUD_HR (19. listopada 2020.).

56 Izvor:http://www.iusinfo.com.hr/CaseLaws/Content.aspx?SOPI=VSRH2008RevxB 103A2\&Doc=VRHSUD_HR (19. listopada 2020.).

57 Emmerich, V., BGB Schuldrecht-Besonderer Teil, 12. Auflage, C. F. Müller Verlag, Heidelberg, 2009., str. $280-281$. 
Hrvatsko odštetno pravo, čini se, čvrsto stoji na konceptu protupravnosti štetne radnje (Verhaltensunrecht). Tako se, primjerice, u hrvatskoj pravnoj književnosti navodi kako se protupravnost može odnositi samo na štetnu radnju ${ }^{58}$, a takvo stajalište, sudeći prema presudama Rev-x 544/2012-2, Rev 1306/06-2 i Rev 635/08-259, uglavnom zauzima i hrvatska sudska praksa.

Neke presude hrvatskih sudova, međutim, sugeriraju kako će se u određenim slučajevima protupravnost prosuđivati s obzirom na nedopuštenost posljedice do koje je dovelo štetnikovo ponašanje.

U predmetu Pn-6956/06 Gžn-1934 od 19. listopada 2010. godine prosuđivala se odgovornost nakladnika za povredu časti i ugleda određene osobe informacijom objavljenom u sredstvima javnog priopćavanja. Štetnik je, kao nakladnik, objavio informaciju da je oštećenik, koji se kandidirao za mjesto ravnatelja nacionalne novinske agencije, imao tvrtku koja se bavila objavljivanjem pornografske literature. Oštećenik tuži štetnika za naknadu neimovinske štete, držeći da mu je štetnik, objavljivanjem te informacije, povrijedio čast i ugled. Prvostupanjski je sud zaključio kako objavljena informacija, iako činjenično točna, jest objektivno podobna da povrijedi nečiju čast i ugled, ali da u konkretnom slučaju ta povreda nije bilo dovoljno ozbiljna da opravda dosuđivanje neimovinske štete. Županijski sud u Zagrebu, djelujući kao prizivni sud, prihvaća ocjenu prvostupanjskog suda da objavljena informacija jest objektivno podobna da povrijedi nečiju čast i ugled, ali ne prihvaća stajalište prvostupanjskog suda da je riječ o nedovoljno ozbiljnoj povredi pa ukida prvostupanjsku presudu i predmet vraća prvostupanjskom sudu na ponovno odlučivanje.

Kao što je razvidno iz ove presude, nakladnik je objavio informaciju za kojom je postojao interes javnosti te koja je bila činjenično točna i provjerena. U tom pogledu čini se da nakladnik nije učinio ništa što bi njegovu radnju (objavljivanje informacije) činilo a priori protupravnom. On nije objavio netočnu, izmišljenu, irelevantnu ili neprovjerenu informaciju. Prema izraženom stavu Županijskog suda u Zagrebu jedino što je $\mathrm{u}$ ovom slučaju predstavljalo protupravnost nakladnikova postupanja jest "objektivna podobnost" objavljene informacije da povrijedi dostojanstvo, ugled i čast određene osobe. Dakle, štetnikovo postupanje (objavljivanje činjenično točne informacije) nije bilo protupravno per se, već se protupravnost prosuđivala prema (ne)dopuštenosti posljedice njegova postupanja. Budući da je ocijenjeno da je objavljena informacija svojim sadržajem imala objektivnu podobnost povrijediti nečije dostojanstvo, čast i ugled, ocijenjeno je da je štetnik djelovao protupravno. Argumentum a contrario, da se utvrdilo

58 Vidi Klarić; Vedriš, op. cit. u bilj. 1, str. 596.

59 Vidi supra 2.1. 
da objavljena informacija nije imala "objektivnu podobnost" povrijediti nečije dostojanstvo, čast i ugled, ta ista štetnikova radnja (objavljivanje relevantne, činjenično točne i provjerene informacije) bila bi ocijenjena dopuštenom. U tom smislu izgleda da je u ovom slučaju protupravnost štetnikova postupanja utvrđena upravo s obzirom na nedopuštenost posljedice njegova postupanja, a ne s obzirom na nedopuštenost njegove radnje. Čini se, stoga, da ne bi bilo pogrešno zaključiti kako hrvatsko odštetno pravo dopušta mogućnost da protupravnost bude procijenjena kako s aspekta nedopuštenosti štetnikove radnje (Verhaltensunrecht), tako i s aspekta nedopuštenosti posljedice štetnikove radnje (Erfolgsunrecht).

\section{ODNOS PROTUPRAVNOSTI I KRIVNJE}

Sudeći prema stavovima izraženima u hrvatskoj pravnoj književnosti, između protupravnosti i krivnje u hrvatskom pravu postoji vrlo jasna razdjelnica: dok je protupravnost povreda nekog pravnog pravila objektivnog prava, krivnja je subjektivni element kojim se prosuđuje ponaša li se štetnik u konkretnom slučaju u skladu s onim što se od njega očekuje. Ima li se na umu da protupravnost u objektivnom smislu predstavlja opću pretpostavku odgovornosti za štetu, koja mora biti ispunjena u pogledu bilo koje vrste odgovornosti, a da je krivnja posebna pretpostavka koja mora biti ispunjena isključivo kod subjektivne odgovornosti za štetu, jasno razlikovanje protupravnosti u objektivnom smislu i krivnje čini se opravdanim, pa čak i nužnim. Hrvatska sudska praksa, međutim, otkriva kako u određenim slučajevima granica između protupravnosti i krivnje može biti vrlo fluidna, ako uopće i postoji.

Tako je, primjerice, u predmetu Rev 2315/1990-2 od 4. lipnja 2003. godine VSRH odlučivao o zahtjevu za naknadu štete prouzročene rušenjem kuće. ${ }^{60} \mathrm{U}$ postupku je bilo nesporno da je tužitelj bespravno sagradio kuću te da je tuženica - tadašnja općina Split - donijela pravomoćnu odluku o rušenju protupravno sagrađenog objekta. Na temelju te pravomoćne odluke donesen je zaključak o dozvoli rušenja te je tužena prionula rušenju objekta, koje je provedeno miniranjem. Tužitelj je podnio protiv tužene zahtjev za naknadu štete koja mu je nastala time što je tužena, umjesto demontažom, objekt rušila miniranjem, tako da je uništila i građevinski materijal koji se demontažom mogao sačuvati i ponovno upotrijebiti. Nižestupanjski su sudovi prihvatili tužbeni zahtjev te osudili tuženu na naknadu štete. Tužena podnosi reviziju VSRH-u tvrdeći da

60 Izvor:http://www.iusinfo.hr/CaseLaws/Content.aspx?SOPI=VSRH1990RevB2315A 2\&Doc=VRHSUD_HR (19. listopada 2020.). 
u njezinu postupanju nije bilo protupravnosti jer je rušenje izvedeno na temelju pravomoćne odluke o rušenju i zaključka o dozvoli rušenja. VSRH odbacuje prigovor tužene, obrazlažući kako je prilikom rušenja tužena trebala postupati s pažnjom dobrog domaćina i zgradu srušiti tako da tužitelju nastane što manja šteta, kako je to od nje zahtijevao članak 18. stavak 1 . ZOO 1978. ${ }^{61}$ VSRH je stoga zaključio kako se protupravnost ponašanja tužene sastoji upravo u propustu da prilikom rušenja objekta postupi sukladno članku 18. stavku 1. ZOO 1978., odnosno pravilu postupanja s dužnom pažnjom.

Dužna pažnja, odnosno pažnja dobrog domaćina, dobrog gospodarstvenika ili dobrog stručnjaka, kriterij je prema kojem se u hrvatskom odštetnom pravu prosuđuje štetnikova nepažnja, dakle njegova krivnja. ${ }^{62}$ No, u ovom slučaju pažnja dobrog domaćina poslužila je VSRH-u kao kriterij utvrđivanja protupravnosti štetnikova postupanja u objektivnom smislu. To naoko neuobičajeno rješenje nije, međutim, rezultat činjenice da je VSRH pomiješao protupravnost u objektivnom smislu i krivnju, već interesantnog, ali i logički ispravnog zaključivanja VSRH-a. Naime, odlučujući o protupravnosti štetnikova ponašanja VSRH je pošao od dviju premisa: prve, da protupravnost u objektivnom smislu znači protivnost nekom pravnom pravilu objektivnog prava te druge, da članak 18. stavak 1. ZOO 1978., koji nalaže sudionicima obveznih odnosa da postupaju s dužnom pažnjom, predstavlja pravilo objektivnog prava. Na temelju tih dviju premisa VSRH došao je do logički ispravnog zaključka kako osoba koja ne postupa s dužnom pažnjom ujedno postupa objektivno protupravno jer time povrjeđuje objektivno pravo, odnosno zakonsko pravilo koje nalaže subjektima u obveznom odnosu da postupaju s dužnom pažnjom. Na taj način dužna pažnja istovremeno predstavlja kriterij za utvrđivanje krivnje i kriterij za utvrđivanje protupravnosti u objektivnom smislu. Dapače, u ovom konkretnom slučaju sudovi, uključujući i VSRH, nisu sporili da je tužena imala pravo srušiti tužiteljevu kuću, dakle da u tom pogledu njezino ponašanje nije bilo protupravno. Jedino što je VSRH prigovorio tuženici jest da prilikom rušenja kuće nije postupala s dužnom pažnjom. U tom smislu moglo bi se zaključiti da je nepažnja tužene, dakle njezina krivnja, jedini razlog zbog kojeg je VSRH prosudio njezino ponašanje objektivno protupravnim. Na taj način gotovo da su se izbrisale granice između protupravnosti u objektivnom smislu i krivnje.

${ }_{61}$ Članak 18. stavak 1. ZOO 1978. glasio je:

“(1) Sudionik u obveznom odnosu dužan je u izvršavanju svoje obveze postupati s pažnjom koja se u pravnom prometu zahtijeva u odgovarajućoj vrsti obveznih odnosa (pažnja dobrog privrednika odnosno pažnja dobrog domaćina)."

62 Vidi Klarić; Vedriš, op. cit. u bilj. 1, str. 598 - 599; Baretić, op. cit. u bilj. 1, str. 171. 
Sudska praksa, nadalje, sugerira kako ovo preklapanje protupravnosti u objektivnom smislu i krivnje ponekad uvodi na mala vrata skrivljenost štetnikova ponašanja kao kriterij određivanja njegove odgovornosti čak i u slučajevima koji bi se trebali prosuđivati prema pravilima objektivne odgovornosti, čime se ujedno, izgleda, brišu jasne granice između subjektivne i objektivne odgovornosti. Dva slučaja koja su se rješavala pred hrvatskim sudovima, slučaj Rev 724/1991-2 od 19. veljače 1991. godine ${ }^{63}$ i slučaj Rev 735/05-2 od 5. listopada 2005. godine ${ }^{64}$, mogu zorno dočarati ovu tezu.

Slučaj Rev 724/1991-2 od 19. veljače 1991. godine odnosio se na zahtjev za naknadu štete prouzročene motornim vozilom u pogonu. U konkretnom slučaju bila je riječ o tjelesnim ozljedama koje je malodobno dijete zadobilo kada je na njega naletio automobil. U postupku je utvrđeno da se vozač propisno kretao desnom stranom kolnika, dozvoljenom brzinom te u skladu s uvjetima na cesti. Istovremeno, skupina djece propisno se kretala lijevom stranom kolni$\mathrm{ka} \mathrm{u}$ istom smjeru. $\mathrm{U}$ jednom je trenutku djetetu ispala jabuka na kolnik te je ono nekontrolirano pošlo za njom i dospjelo na desnu stranu kolnika. Vidjevši dijete na kolniku, vozač je počeo kočiti i skretati udesno kako bi izbjegao nalet na dijete zbog čega je došlo do izlijetanja vozila s ceste. Unatoč poduzetom kočenju i skretanju udesno, nalet se, sudeći prema mišljenju nižestupanjskih sudova, nije mogao izbjeći. Pri takvom stanju stvari nižestupanjski su sudovi u potpunosti odbili tužbeni zahtjev, držeći da je štetnik u svemu postupao u skladu s propisima, a da je za nastalu štetu isključivo odgovoran oštećenik koji je nekontrolirano stupio na kolnik.

VSRH ukinuo je obje nižestupanjske presude i predmet vratio na ponovno odlučivanje, obrazlažući to činjenicom da nižestupanjski sudovi nisu utvrdili i uzeli u obzir sve relevantne okolnosti konkretnog slučaja. Pritom, VSRH doveo je u pitanje konstataciju nižestupanjskih sudova da štetnik nije postupao protupravno. Tako je VSRH naveo kako Zakon o osnovama sigurnosti na cestama nalaže sudionicima u prometu da su osobito dužni paziti na sigurnost djece, invalida te starijih i nemoćnih osoba. Nadalje, VSRH također je naveo kako su na temelju istog Zakona sudionici u prometu dužni upotrijebiti zvučni signal upozorenja kad god to zahtijevaju razlozi sigurnosti, a poglavito ako se u blizini kolnika nalaze djeca koja ne obraćaju pozornost na promet. Na tom temelju VSRH je zauzeo stav kako se mora pretpostaviti da bi pravovremeno upozorenje zvučnim signalom svratilo djetetovu pozornost na motorno vozilo pa ono ne

63 Izvor: http://www.iusinfo.hr/CaseLaws/Content.aspx?SOPI=VSRH2005RevB735A 2\&Doc=VRHSUD_HR (3. listopada 2020.).

64 Izvor: http://www.iusinfo.hr/CaseLaws/Content.aspx?SOPI=VSRH2005RevB735A $2 \&$ Doc $=$ VRHSUD_HR (3. listopada 2020.). 
bi bez osvrtanja započelo s prelaskom ceste. U tom smislu VSRH je smatrao kako je u postupku bilo potrebno utvrditi je li štetnik upotrijebio zvučni signal upozorenja jer je o tome, očito, ovisila ocjena protupravnosti njegova postupanja.

U predmetu Rev 735/05-2 od 5. listopada 2005. godine sudovi se vode gotovo identičnom racionalizacijom. Predmet se odnosio na zahtjev za naknadu štete maloljetnika koji je u dobi od 14 godina teško ozlijeđen kada je, igrajući se na vagonu parkiranom na ranžirnom kolodvoru, došao u dodir s električnim vodom pod naponom te pretrpio strujni udar. Tuženik je tražio da ga se u potpunosti oslobodi od odgovornosti jer je maloljetni oštećenik sam u potpunosti prouzročio štetu, igrajući se na nedopuštenom i neprimjerenom mjestu. Odlučujući o odgovornosti željezničkog operatera, VSRH konačno presuđuje da je štetnik - željeznički operater - odgovoran za nastalu štetu u 60 \%, a da je maloljetni oštećenik doprinio nastanku štete u $40 \%$. Obrazlažući svoju odluku, VSRH ustvrdio je da je željeznički operater postupao protivno svojim internim pravilima, odnosno Pravilniku o unutarnjem redu željeznica jer nije imao vratnicu kojom bi ogradio opasan prostor te jer nije istaknuo jedan od znakova upozorenja poput "zabranjeno dirati - opasno po život", "zabranjen pristup - opasno po život”. VSRH zaključio je kako je tuženik mogao izbjeći štetne posljedice koje su se dogodile da je ogradio i označio opasan prostor, kako je to bilo predviđeno njegovim internim pravilima. Budući da je to propustio učiniti, sudovi su ga djelomično osudili na naknadu štete.

Nesporno je da se u oba ovdje opisana slučaja odgovornost štetnika prosuđivala prema pravilima objektivne odgovornosti za štetu jer je šteta bila prouzročena opasnom stvari, odnosno opasnom djelatnošću, za koje je u hrvatskom obveznom pravu propisana objektivna odgovornost za štetu. ${ }^{65} \mathrm{U}$ tim je slučajevima, dakle, štetnik trebao odgovarati bez obzira na krivnju, odnosno bez obzira na to je li prilikom prouzročenja štete postupao s dužnom pažnjom. Ipak, odlučujući o odgovornosti štetnika u oba ova slučaja, sudovi su de facto prosuđivali je li štetnik postupao onako kako se to od njega očekivalo, dakle je li postupao s dužnom pažnjom, i to u okviru procjene protupravnosti njegova ponašanja u objektivnom smislu. Naime, kao što to jasno proizlazi iz citiranih presuda, odlučujući o štetnikovoj odgovornosti VSRH je smatrao odlučnim pitanje jesu li tuženici postupali u skladu s važećim propisima, u slučaju Rev 724/1991-2 u skladu s važećim zakonom o sigurnosti prometa na cestama, a u slučaju Rev 735/05-2 u skladu s važećim zakonom i štetnikovim internim pravilima o sigurnosti na željeznici. Pritom, navedeni propisi, među ostalim, uređuju način na koji se osobe na koje se ti propisi odnose trebaju ponašati. U tom smislu, propuštajući pona-

65 Vidi čl. 1045. st. 3. ZOO-a. 
šati se u skladu s tim propisima, štetnik istovremeno postupa nepažljivo, dakle skrivljeno, ali i objektivno protupravno. A kada se takva racionalizacija primijeni na slučajeve objektivne odgovornosti, dolazimo do situacije u kojoj, ocjenjujući protupravnost štetnikova ponašanja u objektivnom smislu, ujedno ocjenjujemo primjerenost njegova ponašanja, dakle krivnju, čime u velikoj mjeri dolazi do brisanja jasnih granica između subjektivne i objektivne odgovornosti za štetu.

\section{KRITERIJI ZA UTVRĐIVANJE PROTUPRAVNOSTI}

Na prvi pogled, utvrditi postoji li ili ne postoji protupravnost u konkretnom slučaju ne bi trebao biti veći problem. Budući da je protupravnost objektivna kategorija, postupanje štetnika u konkretnom slučaju trebalo bi usporediti za zahtjevima koje pred subjekte postavljaju pravila objektivnog prava te na temelju toga utvrditi je li njegovo postupanje bilo protupravno ili nije. Dosadašnje izlaganje, međutim, jasno upućuje na zaključak kako u velikom broju slučajeva utvrđivanje postojanja protupravnosti nije nimalo jednostavno ni jednoznačno. Naime, kao što je to već djelomično pokazalo dosadašnje izlaganje te kao što će to u ovom poglavlju biti detaljnije objašnjeno, protupravnost u objektivnom smislu nije statična, već dinamična kategorija. Stoga, vrlo često neće biti moguće a priori kazati je li neko ponašanje objektivno protupravno ili nije. Naime, hrvatska sudska praksa sugerira kako je prilikom utvrđivanja protupravnosti štetnikova ponašanja potrebno uzeti u obzir niz objektivnih, ali i subjektivnih te niz pravnih, ali i činjeničnih elemenata konkretnog slučaja. Tako, primjerice, prilikom utvrđivanja protupravnosti štetnikova ponašanja hrvatski sudovi vode, među ostalim, računa o naravi i značaju dobara na koje se odnosi konkretan slučaj, stupnju opasnosti vezane uz određenu aktivnost, stupnju povrede zaštitnih propisa, dostupnosti alternativnih metoda zaštite, predvidljivosti nastupanja štetnog događaja. Konačno, sudska praksa upućuje na to da prilikom utvrđivanja primjerenosti postupanja sudionika određenog odštetnopravnog odnosa sudovi u Hrvatskoj vrlo često vode računa o međudjelovanju niza različitih elemenata konkretnog slučaja.

\subsection{Narav i značaj dobara}

Za razliku od pravnih poredaka nekih drugih zemalja, hrvatsko odštetno pravo ne poznaje koncept a priori zakonski zaštićenih prava i interesa. U tom smislu postupanje kojim se povređuje bilo koje subjektivno pravo, bez obzira na to je li ono apsolutnog ili relativnog karaktera, može biti ocijenjeno protupravnim. No, kao što to pokazuje hrvatska sudska praksa, ponekad će značaj 
koje određeno pravo ili interes ima u pravnom poretku presudno utjecati na utvrđivanje postojanja ili nepostojanja protupravnosti. To se ponajprije odnosi na ona prava i interese koji predstavljaju ustavne kategorije pa sudovi - prilikom ocjene jesu li ta prava bila povrijeđena ili je li korištenjem tih prava došlo do povrede nečijih tuđih prava i interesa - u velikoj mjeri ta pitanja prosuđuju kroz prizmu ustavnopravne pozicije tih prava i interesa.

Jedan od slučajeva u kojemu je ustavnopravni položaj povrijeđenog prava bio od presudnog značenja prilikom utvrđivanja protupravnosti štetnikova ponašanja jest presuda VSRH-a Rev 1210/09-2 od 27. travnja 2011. godine. ${ }^{66}$ Slučaj se odnosio na zahtjev za naknadu štete vlasnika nekretnine protiv Republike Hrvatske zbog protupravnog onemogućavanja uživanja i uporabe vlastite nekretnine. Oštećenik je, vjerojatno kao rezultat ratnih događanja, napustio svoju nekretninu koju je Republika Hrvatska, na temelju Zakona o privremenom preuzimanju i upravljanju određenom imovinom, uzela u privremeni posjed te ju je dala na privremenu uporabu obitelji izbjegloj iz Bosne i Hercegovine. Prvostupanjski i drugostupanjski sud odbili su tužbeni zahtjev obrazlažući svoje odluke, među ostalim, stavom da je oštećenikova nekretnina uzeta u posjed na temelju posebnog zakona, dakle da postupanje Republike Hrvatske nije bilo protupravno.

VSRH ukida drugostupanjsku presudu i predmet vraća na ponovno odlučivanje. Pritom VSRH izražava stav kako se ovaj slučaj odnosi na pravo vlasništva te da, u tom smislu, o protupravnosti tuženikova ponašanja nije moguće suditi isključivo na temelju relevantnih pravila ZOO-a o naknadi štete, već ponajprije na temelju mjerodavnih odredaba Ustava i Konvencije za zaštitu ljudskih prava i temeljnih sloboda (dalje u tekstu: Konvencija) ${ }^{67}$ jer je pravo vlasništva zaštićeno Ustavom i Konvencijom. VSRH pritom podsjeća da, na temelju Ustava i Konvencije, svaka fizička i pravna osoba ima pravo na mirno uživanje svojeg vlasništva te da se to pravo može ograničiti jedino u javnom interesu, i to samo uz uvjete predviđene zakonom i općim načelima međunarodnog prava. VSRH je izrazio stav kako je Republika Hrvatska uzela u posjed tužiteljevu nekretninu u javnom interesu i s legitimnim ciljem da se zaštiti napuštena imovina od devastacije i propadanja te da se ujedno riješi stambeno pitanje raseljenih i izbjeglih osoba. No, nakon što je tužitelj podnio zahtjev da mu se njegova nekretnina vrati u posjed, prestala je potreba da država tu nekretninu štiti od devastacije i propadanja te je ostao samo legitiman interes Republike Hrvatske

66 Izvor: http://www.iusinfo.hr/CaseLaws/Content.aspx?SOPI=VSRH2009RevB1210 A2\&Doc=VRHSUD_HR (2. listopada 2020.).

67 Zakon o potvrđivanju Konvencije za zaštitu ljudskih prava i temeljnih sloboda i protokola br. 1, 4, 6, 7 i 11 uz Konvenciju za zaštitu ljudskih prava i temeljnih sloboda, Narodne novine, br. 18/1997. 
da stambeno zbrine raseljene i izbjegle osobe. No taj interes, smatrao je VSRH, ne može imati značaj javnog interesa zbog kojeg bi bilo opravdano onemogućiti tužitelja u uživanju njegova prava vlasništva. Iz tih je razloga VSRH ustvrdio da je, od trenutka od kada je tužitelj podnio zahtjev za vraćanjem svoje nekretnine, Republika Hrvatska protupravno držala njegovu nekretninu u posjedu.

Jasno je iz obrazloženja presude VSRH da je za pitanje utvrđivanja protupravnosti ponašanja tužene u ovom konkretnom slučaju od odsudnog značenja bila upravo činjenica da povrijeđeno dobro uživa ustavnopravnu zaštitu. Da je Republika Hrvatska, na temelju posebnog propisa, privremeno oduzela ili ograničila neko drugo, Ustavom i Konvencijom nezaštićeno subjektivno pravo oštećenika, njezino bi postupanje prema svemu sudeći bilo ocijenjeno kao dopušteno. No, budući da je u ovom slučaju bila riječ o oduzimanju, odnosno ograničavanju prava koje jest zaštićeno Ustavom i Konvencijom, VSRH je o protupravnosti odlučivao ponajprije na temelju posebnih zahtjeva koje pred javnu vlast stavljaju Ustav i Konvencija, a ne na temelju općih pravila odštetnog prava, te je na temelju tih posebnih zahtjeva ocijenio ponašanje tužene protupravnim. Na taj način VSRH je vrlo jasno dao do znanja da je prilikom ocjene protupravnosti nečijega postupanja potrebno, među ostalim, voditi računa o značenju povrijeđenog, odnosno ugroženog dobra, to jest da bi se o protupravnosti jednog te istog postupanja moglo sasvim različito prosuđivati, ovisno o značenju, odnosno naravi povrijeđenog dobra.

Ustavnopravni razlozi bili su odlučni i prilikom utvrđivanja protupravnosti tuženikova ponašanja u predmetu VSRH Rev 613/1993-2 od 16. veljače $1994 .{ }^{68}$ Predmet se odnosio na zahtjev za naknadu štete prouzročene nesavjesnim i obijesno uloženim pravnim lijekom. Na temelju pravomoćne sudske odluke, kojom mu je dosuđena isplata određenog iznosa američkih dolara plativo u domaćoj valuti, tužitelj je protiv tuženika pokrenuo ovrhu. Tuženik je u ovršnom postupku uložio prigovor, i to u potpunosti neobrazložen i poslan brzojavom. Nakon što je njegov prigovor odbijen, tuženik ulaže žalbu protiv odluke o odbijanju prigovora i to zbog načina obračuna kamata, iako kamate uopće nisu bile predmet pravomoćne presude na temelju koje se provodila ovrha. Naknadno je odbijena i žalba tuženika te se tužitelj ipak uspio namiriti, no s određenim zakašnjenjem. U međuvremenu je došlo do promjene u tečaju strane valute tako da je tužitelj u konačnici primio manje negoli bi primio da tuženik nije izjavio prigovor i žalbu u ovršnom postupku. Tužitelj je smatrao da je ulaganjem prigovora i žalbe na rješenje o ovrsi tuženik zlorabio svoja procesna ovlaštenja kako

68 Izvor: http://www.iusinfo.hr/CaseLaws/Content.aspx?SOPI=VSRH1993RevB613A 2\&Doc=VRHSUD_HR (5. listopada 2020.). 
bi odugovlačio s postupkom, čime je tužitelju prouzročio štetu koja se sastojala u manje naplaćenom iznosu.

Prvostupanjski je sud prihvatio tužbeni zahtjev, obrazlažući da su tuženikovi prigovor i žalba bili nesavjesni i obijesno uloženi, čime je tuženik zlorabio svoja procesna ovlaštenja. Drugostupanjski sud preinačuje presudu prvostupanjskog suda i u potpunosti odbija tužbeni zahtjev tužitelja. VSRH potvrđuje drugostupanjsku presudu kojom je odbijen tužbeni zahtjev tužitelja. Obrazlažući svoju odluku, VSRH je istaknuo da su na temelju članka 9. Zakona o parničnom postupku ${ }^{69}$, koji se supsidijarno primjenjuje i u ovršnom postupku, stranke u postupku dužne savjesno koristiti se pravima koja su im priznata tim zakonom. No, isto tako VSRH je podsjetio da je pravo na žalbu Ustavom zajamčeno pravo te da Ustav ne predviđa nikakva posebna pravila o tome što bi žalba morala sadržavati. U tom smislu VSRH izrazio je stav da bi Ustavom zajamčeno pravo na žalbu bilo ograničeno kada bi izjavljeni pravni lijek koji nije posebno obrazložen bio razlogom za naknadu štete.

U ovom je slučaju VSRH očito bio prisiljen vagati između dvaju suprotstavljenih zahtjeva: zahtjeva da strane koriste svoja procesna prava savjesno is dužnom pažnjom, dakle da ne zloporabe svoja prava te Ustavom predviđenog zahtjeva da pravni subjekti imaju pravo na žalbu. Važući između ta dva suprotstavljena zahtjeva, VSRH je očito odlučio dati prednost potonjem.

Kao što to jasno proizlazi iz članka 9. Zakona o parničnom postupku te kao što je to jasno potvrdio i VSRH u ovom predmetu, stranke su dužne savjesno se koristiti procesnim pravima koje im zakon daje. Ako bi se stranka nesavjesno koristila svojim pravom, takvo bi postupanje moglo biti ocijenjeno kao zloporaba prava, dakle protupravno, kao što je to, primjerice, zaključio VSRH u predmetu 976/07-2.

Izgleda, međutim, da ova racionalizacija vrijedi za svako drugo procesno pravo, osim za pravo na žalbu. Naime, kao što je to jasno naglasio VSRH, pravo na žalbu Ustavom je zajamčeno pravo i kao takvo ono ne bi smjelo biti ograničeno. Ograničavanje prava na žalbu, pa čak i putem primjene pravila o zabrani zloporabe prava, moglo bi dovesti do povrede Ustava. Naime, kada bi u svakom konkretnom slučaju sudovi mogli odlučivati je li, ulažući žalbu, određeni subjekt zlorabio svoje pravo, to bi vrlo vjerojatno odvratilo subjekte od slobodnog korištenja Ustavom zajamčenog prava na žalbu.

69 Zakon o parničnom postupku, SL SFRJ, br. 4/1977, 36/1977, 6/1980, 36/1980, 43/1982, 69/1982, 58/1984, 74/1987, 57/1989, 20/1990, 27/1990, 35/1991, Narodne novine, br. 53/1991, 91/1992, 58/1993, 112/1999, 88/2001, 117/2003, 88/2005, 02/2007, 84/2008, 96/2008, 123/2008, 57/2011, 148/2011, 25/2013, 89/2014, 70/2019. 
Čini se, stoga, da bi se na temelju ove odluke moglo zaključiti kako VSRH drži da opći društveni interes da se omogući građanima slobodno koristiti se svojim ustavnim pravom na žalbu bez straha od potencijalne odštetnopravne odgovornosti nadilazi interes, odnosno zahtjev da se procesna prava ne zlorabe. Stoga, prilikom ocjene zlorabi li određeni subjekt svoje subjektivno pravo i na taj način postupa protupravno od presudnog će značenja biti pitanje je li riječ o Ustavom zaštićenom pravu te hoće li, eventualnim utvrđenjem da je subjekt zlorabio takvo svoje pravo, doći do neprimjerenog ograničenja toga prava, a time i do povrede Ustava.

\subsection{Stupanj opasnosti vezane uz određenu aktivnost}

Hrvatska sudska praksa upućuje na to kako, ovisno o stupnju opasnosti vezane uz određenu aktivnost, pravni poredak postavlja pred subjekte različita očekivanja. U tom smislu postupanje koje bi se u normalnim okolnostima ocijenilo primjerenim, u situacijama u kojima postoji povećana opasnost od nastanka štete, može biti ocijenjeno neadekvatnim, odnosno protupravnim.

Ilustrativan primjer $\mathrm{u}$ tom pogledu već je spomenuta presuda VSRH-a u predmetu Rev 724/1991-2 od 19. veljače 1991. godine..$^{70}$ Predmet se odnosio na zahtjev za naknadu štete maloljetnog oštećenika koji je ozlijeđen prilikom prometne nesreće do koje je došlo kada je oštećenik nekontrolirano stupio na kolnik. Budući da je tijekom postupka utvrđeno da je štetnik propisno upravljao vozilom, krećući se dozvoljenom brzinom i u skladu s uvjetima na cesti, odnosno da, kako je to utvrdio sudski vještak, štetnik nije mogao učiniti ništa da izbjegne prometnu nesreću, nižestupanjski su sudovi odbili tužbeni zahtjev, držeći da je za štetu isključivo odgovoran maloljetni oštećenik. VSRH ukinuo je nižestupanjske presude ne slažući se s karakterizacijom ponašanja štetnika od strane nižestupanjskih sudova. VSRH je ustvrdio kako djeca na cesti predstavljaju povećanu opasnost, odnosno povećani rizik od nastupanja štete te da im zbog toga relevantni propisi pružaju posebnu zaštitu, nalažući sudionicima u prometu neke specifične dužnosti kojima u normalnim okolnostima ne bi bili obvezani. Tako je, u ovom konkretnom slučaju, VSRH ustvrdio da je vozač trebao upotrijebiti zvučni signal kako bi djecu upozorio na nadolazeće vozilo.

Iz ovog je slučaja jasno da su kriteriji po kojima se prosuđuje primjerenost štetnikova ponašanja različiti, ovisno o stupnju rizika koji je vezan uz određenu djelatnost. U svakoj drugoj situaciji, koja ne bi involvirala djecu ili neku drugu ranjivu skupinu poput invalida, starijih i nemoćnih osoba, ponašanje štetnika

70 Vidi supra 5. 
bilo bi ocijenjeno primjerenim. No, budući da su u ovom konkretnom slučaju bila involvirana djeca, koja uživaju posebnu zaštitu jer predstavljaju povećanu opasnost u prometu, VSRH je zaključio kako su sudionici u prometu podvrgnuti dužnosti povećane pažnje te da ono ponašanje koje bi u normalnim okolnostima bilo primjereno, u slučaju povećane opasnosti neće biti dovoljno da se štetnika oslobodi odgovornosti.

Kao što je već ranije naglašeno, ono što je u ovom slučaju osobito zanimljivo jest da su se sudovi upustili u raspravljanje primjerenosti štetnikova postupanja iako je bila riječ o slučaju objektivne odgovornosti. Naime, je li prilikom vožnje štetnik učinio sve što je trebao kako bi izbjegao nastupanje štetne posljedice, obično je kriterij kojim se utvrđuje nečija krivnja. No, tu vrstu ocjene sudovi su ovdje upotrijebili u slučaju objektivne odgovornosti, prosuđujući objektivnu protupravnost štetnikova djelovanja. Takav pristup suda pitanju određivanja protupravnosti štetnikova postupanja rezultat je činjenice da objektivno pravo vrlo često propisuje određene dužnosti kojih se subjekti u određenom odnosu moraju pridržavati. Na taj način, postupajući protivno tim propisanim dužnostima, štetnik istovremeno postupa skrivljeno i protupravno. Zbog toga prilikom odlučivanja o odgovornosti štetnika prema pravilima objektivne odgovornosti sudovi često primjenjuju iste one kriterije prema kojima bi prosuđivali štetnikovu krivnju kod subjektivne odgovornosti.

\subsection{Stupanj povrede zaštitnih propisa}

U slučajevima u kojima propisi određuju na koji se način subjekti moraju ponašati u određenoj situaciji, intenzitet povrede tog propisa u pravilu neće utjecati na utvrđivanje protupravnosti štetnika. Načelno, svaka povreda takvog propisa koja je u uzročno-posljedičnoj vezi s nastupanjem određene štete trebala bi biti ocijenjena protupravnom. Ipak, sudska praksa upućuje na to kako će u određenim, doduše rijetkim i specifičnim situacijama, prilikom utvrđivanja protupravnosti štetnikova ponašanja biti odlučan upravo intenzitet povrede propisa.

Tako je u predmetu Pn-1122/07 Gžn-3740/08 od 24. svibnja 2011. godine Županijski sud u Zagrebu izrazio stav kako se prilikom nanošenja štete u sportu protupravnim može smatrati samo ono ponašanje kojim se grubo krše pravila sportske igre. Ovaj se slučaj odnosio na odštetni zahtjev sportaša koji je bio ozlijeđen od strane igrača protivničke momčadi tijekom održavanja meča. Odlučujući o protupravnosti štetnikova ponašanja, Županijski je sud u Zagrebu ponajprije pošao od stajališta da protupravnost u sportskoj igri označava ponašanje koje je suprotno pravilima određenog sporta, dakle da je u sportu protupravno ono ponašanje koje je nepodudarno s određenim pravilima po kojima se to pona- 
šanje prosuđuje, odnosno koje vrijeđa pravila sportske igre. No, pritom je taj sud također ustvrdio kako se u sportu protupravnost mjeri u odnosu na rizik koji se preuzima sudjelovanjem u određenoj sportskoj aktivnosti te da se, $\mathrm{u}$ tom pogledu, protupravnim može smatrati samo grubo nesportsko ponašanje, odnosno samo ono ponašanje kojim se teže krše pravila sportske igre. Budući da u konkretnom slučaju sudovi nisu utvrdili takav teži stupanj povrede pravila sportske igre, odbili su tužbeni zahtjev.

Ovaj slučaj, dakle, jasno pokazuje da će u određenim situacijama samo teže povrede propisa dovesti do protupravnosti štetnikova ponašanja. No, postavlja se pitanje što je razlog da se u određenim situacijama odgovara isključivo za teže povrede propisa, odnosno koji je to kriterij prema kojem ćemo razlikovati slučajeve u kojima samo teža povreda propisa dovodi do protupravnosti od onih slučajeva u kojima svaka povreda propisa, bez obzira na njezin intenzitet, dovodi do protupravnosti štetnikova ponašanja. Sud je u ovom slučaju jasno definirao taj kriterij: to je rizik koji oštećenik preuzima pristajanjem na sudjelovanje u određenoj sportskoj igri. Pritom, sud se izričito pozvao na volenti non fit iniuria pravilo iz članka 163. ZOO 1978. Dakle, budući da je sportskoj igri, poglavito tzv. kontaktnim sportovima, imanentna opasnost nastupanja određene štete, pristankom na sudjelovanje u takvoj igri sportaši preuzimaju dio rizika nastupanja štete na sebe, odnosno pristaju na mogućnost da im se dogodi određena šteta. U tom smislu oni koji u okviru takve igre drugome prouzroče štetu ne bi trebali za nju odgovarati jer je njihova protupravnost isključena pristankom oštećenika na poduzimanje radnje od koje bi mu mogla nastati šteta.

Primjenjujući, međutim, pravilo volenti non fit iniuria na ovaj slučaj, sud je ipak do određene mjere modificirao to pravilo, odnosno primijenio ga cum grano salis. Naime, radikalno tumačenje toga pravila moglo bi sugerirati da sportaši, pristajući sudjelovati u sportskom natjecanju, ujedno pristaju na mogućnost nastupanja svake štete koja se u okviru sportskog natjecanja može dogoditi, uključujući i one prouzročene grubim povredama sportske igre. Županijski sud u Zagrebu očito je smatrao takvo ekstremno tumačenje pravila volenti non fit iniuria neprihvatljivim. Taj je sud očito pošao od sasvim prihvatljivog stajališta da pristankom na sudjelovanje u sportskom natjecanju sportaši pristaju na uobičajene štete, odnosno na one povrede koje bi se uobičajeno mogle dogoditi "u žaru borbe". No, nitko, pa ni sportaši, pristankom na sudjelovanje u određenoj aktivnosti koja po redovitom tijeku nosi povećanu opasnost od nastupa štete ne bi trebali pristajati na štete koje su prouzročene izlaskom iz okvira onoga što se smatra redovitim tijekom stvari. U tom smislu sama povreda pravila sportske igre koja se kreće u okvirima uobičajenog, odnosno očekivanog u okviru te sportske igre, neće se smatrati protupravnom. S druge strane, gruba povreda pravila sportske 
igre izlazi izvan okvira onoga što je uobičajeno, odnosno očekivano te se zbog toga može smatrati protupravnom.

Zanimljivo je također primijetiti da je i u ovom slučaju došlo do određenog ispreplitanja subjektivnog i objektivnog elementa protupravnosti. Naime, govoreći o protupravnosti štetne radnje u sportu, Županijski je sud u Zagrebu ustvrdio da bi se protupravnim moglo smatrati ono ponašanje koje se može kvalificirati kao grubo nesportsko ponašanje, namjerni prekršaj, gruba nepažnja, odnosno surova igra. Dakle, prosuđujući o objektivnoj protupravnosti štetnikove radnje, sud se ujedno pozvao na kriterije koji se uobičajeno primjenjuju prilikom utvrđivanja štetnikove krivnje.

Iako ova presuda može zorno ilustrirati tezu kako će u određenim slučajevima samo teža povreda pravila biti protupravna, u njoj izraženi pravni stav ne bi trebalo generalizirati i a priori širiti izvan okvira sportskih aktivnosti, o kojima je sud u ovom slučaju odlučivao. Naime, niz je ljudskih aktivnosti koje involviraju povećanu mogućnost nastanka štete. Kada bismo stav suda izražen u ovom predmetu prihvatili kao općenit stav, koji se primjenjuje na svaku aktivnost koja po redovitom tijeku stvari nosi sa sobom povećanu mogućnost nastanka šteta, lako bismo mogli doći do objektivno neprihvatljivih rješenja. Naime, jedna od aktivnosti u kojima po prirodi stvari postoji povećana mogućnost nastanka štete jest medicinska djelatnost. Kada bismo racionalizaciju suda iz ovog predmeta primijenili na medicinsku djelatnost, morali bismo zaključiti da je samim pristankom na sudjelovanje u određenom medicinskom zahvatu pacijent ujedno prihvatio da se neće svaka povreda pravila medicinske struke od strane liječnika smatrati protupravnom, već da će se protupravnima smatrati tek teže povrede pravila te struke. Takvo bi razmišljanje u okvirima medicinske djelatnosti bilo u potpunosti neprihvatljivo. Zbog toga bi u pogledu svake pojedine aktivnosti trebalo posebno prosuđivati postoje li pretpostavke da se ratio koje je sud primijenio u ovom slučaju primjene i na te aktivnosti.

\subsection{Dostupnost alternativnih metoda zaštite}

Odlučujući o tome je li postupanje štetnika bilo primjereno sudovi će, kao što to pokazuje naša sudska praksa, među ostalim voditi računa i o tome jesu li štetniku na raspolaganju bile neke alternativne, odnosno dopunske metode zaštite te je li ih štetnik primijenio.

Tako je, u već spomenutom slučaju Rev 735/05-2 od od 5. listopada 2005. godine $^{71}$, odlučujući o odgovornosti željezničkog operatera za štetu prouzro-

71 Vidi supra 5. 
čenu maloljetniku koji je igrajući se na krovu parkiranog željezničkog vagona ozlijeđen strujnim udarom uslijed kontakta s električnim vodom pod naponom, VSRH zaključio kako su štetniku, osim onih koje je primijenio, na raspolaganju bile mnoge druge metode zaštite od štetnog događaja, kao što je postavljanje zaštitne vratnice ili postavljanje odgovarajućih upozorenja o opasnosti, ali da štetnik nije primijenio niti jednu od njih, zbog čega je sud zaključio da je štetnik doprinio nastanku štete.

U slučaju Pn-4181/6 Gžn-3905/08 od 16. prosinca 2008. godine Županijski sud u Zagrebu odlučivao je o odgovornosti trgovačkog centra za štetu koju je pretrpio posjetitelj kojeg su prilikom ulaska u trgovački centar udarila staklena pokretna vrata. Prvostupanjski je sud utvrdio da su u trenutku nastupanja štetnog događaja ulazna vrata ispravno funkcionirala te da je na njima bila vidljivo istaknuta naljepnica koja je označavala radno vrijeme trgovačkog centra. Pregledom snimki sigurnosnih kamera zaključeno je da se štetni događaj dogodio kada se oštećenik, prošavši prva staklena pomična vrata, krećući se prebrzo i gledajući u pod, zaletio u druga staklena pomična vrata. Na temelju takvih utvrđenja prvostupanjski je sud zaključio kako je za nastanak štete isključivo odgovoran oštećenik te je odbio njegov tužbeni zahtjev. Odlučujući u povodu Žalbe oštećenika, Županijski je sud u Zagrebu poglavito provjeravao je li trgovački centar učinio sve što je mogao da do nezgode ne dođe. U tom smislu Županijski je sud posebno cijenio činjenicu da je na staklenim vratima bila vidljivo istaknuta naljepnica koja je označavala radno vrijeme. Prema mišljenju Županijskog suda u Zagrebu, ta je naljepnica, osim očite svrhe prikazivanja radnog vremena trgovačkog centra, služila i tome da upozori ljude da se približavaju prozirnim vratima. Na temelju te činjenice kao i na temelju činjenice da su ulazna vrata u trenutku nastupa štetnog događaja ispravno funkcionirala, Županijski je sud u Zagrebu odbio žalbu tuženika i potvrdio prvostupanjsku presudu.

U oba navedena slučaja sudovi su, ocjenjujući primjerenost štetnikova postupanja, provjeravali među ostalim je li štetnik primijenio sve raspoložive mjere opreza, odnosno izbjegavanja nastupanja štetnog događaja. U slučaju Rev 735/05-2 bilo je, doduše, utvrđeno da je prostor ranžirnog kolodvora na kojemu se nalazio vagon bio djelomično ograđen. No, ocjenjujući štetnikovu odgovornost, sudovi su osobito uzeli u obzir činjenicu da su relevantni propisi i interna pravila štetnika predviđala i neke druge, alternativne mjere opreza kao što je, primjerice, postavljanje zaštitne vratnice i postavljanje odgovarajućih znakova opasnosti, odnosno upozorenja na opasnost, koje štetnik nije primijenio. S druge strane, u slučaju Pn-4181/6 Gžn-3905/08 sudovi su oslobodili tuženika odgovornosti upravo zbog toga što su ocijenili da je u konkretnom slučaju tuženik učinio sve što je trebao da do štetnog događaja ne dođe, odnosno zbog toga što nije 
bilo nikakvih alternativnih ili dodatnih mjera zaštite koje je tuženik mogao primijeniti da izbjegne nastupanje štetnog događaja.

Ono što je i u pogledu ovih predmeta zanimljivo jest činjenica da su sudovi ocjenjivali primjerenost postupanja štetnika na potpuno identičan način, posebno ocjenjujući je li štetnik poduzeo sve što je mogao da do štete ne dođe, i to unatoč tome da je slučaj Rev 735/05-2 prosuđivan po pravilima objektivne, a slučaj Pn-4181/6 Gžn-3905/08 po pravilima subjektivne odgovornosti. U tom smislu i na ovom je mjestu umjesno primijetiti kako su sudovi prosuđivali postojanje protupravnosti tuženikova postupanja, među ostalim, na temelju kriterija dužne pažnje, dakle kriterija koji se uobičajeno koristi prilikom prosuđivanja štetnikove krivnje, dakle subjektivnog elementa protupravnosti.

\subsection{Međudjelovanje pojedinih kriterija za utvrđivanje primjerenosti postupanja}

Konačno, kao što je već naglašeno, prilikom procjene primjerenosti postupanja sudionika određenog štetnog događaja, a poglavito prilikom raspodjele odgovornosti na pojedine sudionike, hrvatski sudovi vrlo često istodobno uzimaju u obzir niz različitih kriterija. Osim onih koji su već spomenuti u prethodnim točkama ovog poglavlja, sudovi učestalo koriste i neke dodatne kriterije kao što su dob subjekata, njihova tjelesna ili neka druga ograničenja, svijest o opasnosti određenog postupanja. Pritom, kao što će to biti prikazano, odluka suda o utvrđivanju odgovornosti te o raspodjeli te odgovornosti među različitim sudionicima određenog štetnog događaja u velikoj će mjeri biti uvjetovana međudjelovanjem pojedinih od tih kriterija.

U tom je smislu ilustrativan predmet Rev 909/2008-2 od 23. veljače 2010. $\operatorname{godine}^{72}$, u kojem su sudovi prosuđivali odgovornost za štetu prouzročenu prometnom nezgodom do koje je došlo kada je vozilo na pješačkom prijelazu naletjelo na 67-godišnjeg pješaka. Tijekom prvostupanjskog postupka utvrđeno je da je vozač prolazio kroz križanje dok je za njegov smjer bilo upaljeno zeleno svjetlo, vozeći $60 \mathrm{~km} / \mathrm{h}, 10 \mathrm{~km} / \mathrm{h}$ više od dopuštene brzine, kada je preko ceste počeo prelaziti 67-godišnji pješak, kojemu je u tom trenutku za njegov smjer kretanja bilo upaljeno crveno svjetlo. Na temelju nalaza i mišljenja vještaka vozač nije mogao spriječiti sudar ni pri dopuštenoj brzini od $50 \mathrm{~km} / \mathrm{h}$ jer je do izbjegavanja naleta na pješaka moglo doći jedino pri brzini od $42,8 \mathrm{~km} / \mathrm{h}$ i nižoj. Na temelju tako utvrđenog činjeničnog stanja nižestupanjski su sudovi

72 Izvor: http://www.iusinfo.hr/CaseLaws/Content.aspx?SOPI=VSRH2008RevB909A 2\&Doc=VRHSUD_HR (15. listopada 2020.). 
ocijenili doprinos štetnika nastanku štete u iznosu od 30 \% i doprinos oštećenika u iznosu od $70 \%$.

Ocjenjujući protupravnost postupanja štetnika i oštećenika, sudovi su prije svega uzeli u obzir je li, i u kojoj mjeri, njihovo postupanje bilo usklađeno s mjerodavnim propisima. Sudovi su tako utvrdili da je štetnik doduše povrijedio propise koji se odnose na sigurnost prometa jer vozio brzinom većom od dopuštene. No, tu činjenicu nisu mu uzeli za zlo jer je tijekom postupka utvrđeno da prekoračenje brzine nije bilo u uzročnoj vezi s nastupanjem štetnog događaja, odnosno da bi štetni događaj nastupio čak i da je štetnik vozio dopuštenom brzinom. Ono u čemu su sudovi vidjeli protupravnost štetnikova postupanja jest njegov propust da predvidi mogućnost nastupanja zapreke na cesti te da prilagodi svoju vožnju uvjetima na cesti, čime je štetnik, prema viđenju sudova, povrijedio propise kojima je uređena sigurnost prometa na cestama. Ocjenjujući protupravnost postupanja oštećenika, VSRH je prije svega istaknuo činjenicu da je oštećenik povrijedio važeće propise o sigurnosti prometa na cestama, prelazeći cestu dok je za njegov smjer kretanja bilo upaljeno crveno svjetlo. Osim toga, VSRH je posebno istaknuo oštećenikovu dob koja ga je, s jedne strane, činila dovoljno zrelim da uvidi protupravnost i veliku opasnost svojeg postupanja, a s druge strane, trebala podsjetiti na fizička ograničenja te dobi. Povrh toga, VSRH posebno je prigovorio oštećeniku činjenicu da se štetni događaj dogodio u blizini njegove kuće, dakle u njemu poznatom okružju, što ga je moralo činiti svjesnim opasnosti prometnice koju je prelazio. Zbog svih tih razloga VSRH ocijenio je postupanje oštećenika kao "krajnje neodgovorno" i kao "teži stupanj neadekvatnosti”.

Iz navedenog je razvidno da je odluka o raspodjeli odgovornosti među sudionicima štetnog događaja bila rezultat ocjene i suptilnog vaganja niza različitih kriterija za ocjenu primjerenosti, odnosno neprimjerenosti postupanja sudionika tog štetnog događaja. Tako su sudovi prije svega uzeli u obzir zakonski okvir te procjenjivali je li i u kojoj mjeri postupanje sudionika štetnog događaja bilo u skladu sa zakonskim propisima te je li i u kojoj mjeri povreda propisa doprinijela nastanku štete. Osim toga, sudovi su, prilikom procjene adekvatnosti štetnikova i oštećenikova postupanja, uzeli u obzir niz dodatnih kriterija, poput predvidljivosti nastupanja štetnog događaja, dobi sudionika štetnog događaja i postojanja svijesti o povećanoj opasnosti, pa su tako protupravnost štetnikova postupanja utvrdili na temelju činjenice da je propustio predvidjeti nastupanje zapreke na cesti, dok su pak protupravnost oštećenikova postupanja, osim na temelju nesporne povrede sigurnosnih propisa, utvrdili i na temelju činjenice da je oštećenik postupao neprimjereno svojoj dobi i njezinim fizičkim ograničenjima te da je zanemario opasnost njemu poznate okoline.

Konačno, iz navedenoga također jasno proizlazi da su sudovi i u ovom slučaju, prosuđujući o protupravnosti postupanja sudionika štetnog događaja, 
osim kriterija objektivne povrede propisa ujedno uzeli u obzir niz subjektivnih elemenata konkretnog događaja, iako je bila riječ o primjeni pravila objektivne odgovornosti.

\section{ZAKLJUČCI}

Ovim se radom nastojalo pronaći odgovore na neka temeljna pitanja vezana uz protupravnost $\mathrm{u}$ hrvatskom odštetnom pravu kao što su: je li protupravnost pretpostavka odgovornosti za štetu, u čemu se protupravnost sastoji, na što se protupravnost odnosi, u kakvom je odnosu protupravnost s krivnjom kao pretpostavkom odgovornosti te na temelju kojih se kriterija protupravnost utvrđuje. Analiza hrvatske sudske prakse koja je korištena u ovom radu nedvosmisleno upućuje na to da je protupravnost puno složeniji i dinamičniji institut od onoga što sugerira hrvatska pravna književnost.

Prije svega, hrvatska sudska praksa jasno podupire zaključak kako protupravnost jest pretpostavka odgovornosti za štetu u hrvatskom odštetnom pravu. ${ }^{73} \mathrm{U}$ tom smislu čak ako je određena radnja štetnika dovela do nastupanja štete, štetnik neće biti odgovoran ako se utvrdi da njegovo postupanje nije bilo protupravno. ${ }^{74}$ Pritom, suprotno od onoga što ponekad zagovara pravna književnost, sama povreda načela zabrane prouzročenja štete, predviđenog u članku 8. ZOO-a, neće biti dovoljna za nastupanje odštetnopravne odgovornosti. Osim toga, bit će potrebno utvrditi da se nastupanje štete na neki način može pripisati neadekvatnosti štetnikova postupanja. ${ }^{75}$ Nadalje, hrvatska sudska praksa jasno potvrđuje da je protupravnost samo jedna od pretpostavka koje se kumulativno moraju ispuniti da bi došlo do odgovornosti za štetu. U tom smislu protupravnost određenog postupanja neće dovesti do odgovornosti za štetu ako iz tog protupravnog postupanja nije proizašla nikakva šteta, odnosno ako nastala šteta nije u uzročnoj vezi s protupravnošću postupanja određenog subjekta. ${ }^{76}$ Konačno, iako protupravnost u načelu jest opća pretpostavka odgovornosti za štetu, u hrvatskom će se pravu, u određenim, zakonom izrijekom predviđenim slučajevima, odgovarati i bez protupravnosti postupanja odgovorne osobe. ${ }^{77}$

73 Vidi presude Rev-x 544/2012-2, Rev 1306/06-2, Rev 635/08-2, Gzz-39/03-3, Rev503/08-2, supra 2.1 .

74 Vidi presude Rev 1535/1990-2, Rev-x 544/2012-2, supra 2.1.

75 Vidi presude Pn-6472/00 Gžn-2882/07, Rev-63508-2, supra 2.1.

76 Vidi presude Rev 635/08-2, Pn-1992/85 Gž-13/88, Gž-2584/14-2, supra 2.3.

77 Vidi supra 2.2 . 
Iako se o protupravnosti učestalo govori kao o povredi pravnog propisa, odnosno povredi pravila objektivnog prava, hrvatska pravna književnost ne eksplicira na što se pod tim terminima zapravo misli. Analiza sudske prakse upućuje na to kako protupravnost u objektivnom smislu znači protivnost štetnikova postupanja kako zakonskim, tako i izvanzakonskim, autonomnim izvorima pravila ponašanja, i to bez obzira je li riječ o pisanim ili nepisanim pravilima ponašanja. U pogledu povrede pravnih propisa sudska praksa pokazuje kako se protupravnost može sastojati u povredi ustavnih normi ${ }^{78}$, normi međunarodnih konvencija te normi važećih zakona. ${ }^{79}$ Pritom ne mora nužno biti riječ o zakonima iz područja građanskog prava, već i o zakonima iz drugih pravnih područja. Tako se, primjerice, u hrvatskoj sudskoj praksi protupravnost utvrđivala na temelju zakona kojima se uređuje sustav državne uprave ${ }^{80}$, sigurnost prometa na cestama ${ }^{81}$, sigurnost željezničkog prometa ${ }^{82}$, medicinska djelatnost ${ }^{83}$, lovstvo. ${ }^{84}$ Hrvatska sudska praksa također sugerira kako se, osim u povredi Ustava, međunarodnih konvencija i zakona, protupravnost može sastojati i u povredi nekih podzakonskih akata ${ }^{85}$, pa čak i pojedinačnih akata donesenih na temelju općih pravnih akata. ${ }^{86}$

Osim toga, protupravnost se može sastojati i u povredi nekih autonomnih pravila ponašanja, i to bez obzira je li riječ o pisanim ili nepisanim pravilima. U tom smislu hrvatska je sudska praksa o protupravnosti štetnikova postupanja prosuđivala na temelju internih pravila određenog trgovačkog društva ${ }^{87}$, pravila crkvenog reda ${ }^{88}$, pravila sportske organizacije ${ }^{89}$, odnosno općenito pravila određenog sporta ${ }^{90}$, pravila određene struke, poput medicinske ${ }^{91}$ ili veterinarske. ${ }^{92}$

\footnotetext{
78 Vidi presudu Gzp 1014/09-3, supra 3.

79 Vidi presudu Rev 713/98, supra 3.

80 Vidi presudu 635/08-2, supra 3.

81 Vidi presudu Pn 1995/85 Gž-13/88, supra 3.

82 Vidi presudu Rev 735/05-2, supra 3.

83 Vidi presudu Pn-6472/00 Gžn-2882/07, supra 3.

84 Vidi presudu Rev-x 32/2010-2, supra 3.

85 Vidi presude Rev 114/2004-2, Rev-92/2008-2, supra 3.

86 Vidi presudu Rev 242/2003-2, supra 3.

87 Vidi presudu Rev 735/05-2, supra 3.

88 Vidi presudu Rev 917/1990-2, supra 3.

89 Vidi presudu Pn-7434/05 Gžn 1606/11, supra 3.

90 Vidi presudu Rev 1194/90, supra 3.

91 Vidi presudu Pn-6472/00 Gžn-2882/07, supra 3.

92 Vidi presudu Rev 1671/1990-2, supra 3.
} 
Konačno, kao što to potvrđuje sudska praksa, o protupravnosti se može govoriti i u slučajevima povrede ugovorom predviđenih obveza. ${ }^{93}$

Kad se govori o protupravnosti u hrvatskom pravu, vrlo se često napominje da se protupravnost može odnositi isključivo na štetnu radnju, što bi sugeriralo da hrvatsko odštetno pravo prihvaća koncepciju protupravnosti štetne radnje (Verhaltensunrecht). No, pojedine presude hrvatskih sudova upućuju na zaključak da hrvatsko pravo također prihvaća koncepciju protupravnosti posljedice (Erfolgsunrecht) pa će, u određenim situacijama, neko načelno dopušteno postupanje ipak biti ocijenjeno protupravnim ako dovodi do nedopuštene posljedice. ${ }^{94}$

Analiza provedena u ovom radu također jasno upućuje na to kako protupravnost nije statična, već dinamična kategorija te često neće biti moguće a priori ustvrditi je li neko ponašanje objektivno protupravno, već će prilikom utvrđivanja protupravnosti štetnikova ponašanja biti potrebno uzeti u obzir niz objektivnih, ali i subjektivnih te niz pravnih, ali i činjeničnih elemenata konkretnog slučaja. Tako, primjerice, prilikom utvrđivanja protupravnosti štetnikova ponašanja hrvatski sudovi vode, među ostalim, računa o naravi i važnosti prava i interesa na koje se odnosi konkretan slučaj’5, o stupnju opasnosti vezane uz određenu aktivnost ${ }^{96}$, o stupnju povrede zaštitnih propisa ${ }^{97}$, o dostupnosti alternativnih metoda zaštite ${ }^{98}$, o predvidljivosti nastupanja štetnog događaja. ${ }^{99}$ Konačno, provedena analiza pokazuje da prilikom utvrđivanja primjerenosti, odnosno neprimjerenosti postupanja sudionika određenog odštetnopravnog odnosa sudovi u Hrvatskoj vrlo često vode računa o međudjelovanju različitih elemenata konkretnog slučaja. ${ }^{100}$

Istraživanje provedeno $\mathrm{u}$ ovom radu pokazuje vrlo zanimljive rezultate $\mathrm{u}$ pogledu odnosa protupravnosti i krivnje. Naime, hrvatska pravna književnost sugerira kako između protupravnosti u objektivnom smislu i krivnje postoji jasna razdjelnica. No, te bi stavove trebalo uzeti s dozom opreza jer sudska praksa zorno pokazuje kako je u pojedinim slučajevima granica između objektivne protupravnosti i krivnje vrlo fluidna, ako uopće i postoji. Rezultat je to činjenice da ZOO, ali i niz posebnih propisa nameću sudionicima obveznih

\footnotetext{
93 Vidi presudu Rev x 103/08-2, supra 3.

94 Vidi presudu Pn-6956/06 Gžn-1934, supra 4.

95 Vidi presude Rev 1210/09-2, Rev 613/1993-2, supra 6.1.

96 Vidi presudu Rev 724/1991-2, supra 6.2.

97 Vidi presudu Pn-1122/07 Gžn-3740/08, supra 6.3.

98 Vidi presude Rev 735/05-2, Pn-4181/6 Gžn-3905/08, supra 6.4.

99 Vidi presudu Rev 909/208-2, supra 6.5.

100 Vidi presudu Rev 909/208-2, supra 6.5.
} 
odnosa određene dužnosti postupanja, poput, primjerice, dužnosti postupanja s dužnom pažnjom, odnosno pažnjom dobrog domaćina, gospodarstvenika ili stručnjaka. U tom smislu povreda dužne pažnje, koja se uobičajeno koristi kao kriterij određivanja nečije krivnje, vrlo često ujedno biva kriterij ocjenjivanja protupravnosti štetnikova postupanja u objektivnom smislu jer netko tko ne postupa s dužnom pažnjom, ujedno povrjeđuje zakonsko pravilo koje sudionicima nameće obvezu postupanja s dužnom pažnjom. Tako je u određenim slučajevima koji su se rješavali pred hrvatskim sudovima postupanje štetnika bilo ocijenjeno kao protupravno isključivo na temelju činjenice da štetnik nije postupao s dužnom pažnjom. ${ }^{101}$

To ujedno sugerira kako pretjerano inzistiranje na striktnom razdvajanju subjektivnog i objektivnog elementa protupravnosti može djelovati artificijelno, ponekad čak i kontraproduktivno. Izgleda, naime, da je u našem pravu, baš kao i u francuskom, protupravnost strukturno složen, ali ujedno i jedinstven institut koji u sebi involvira niz međusobno isprepletenih i međusobno uvjetovanih objektivnih i subjektivnih elemenata. U tom smislu čini se da prosudba adekvatnosti ponašanja sudionika nekog odštetnopravnog odnosa neće biti moguća bez da se istovremeno ne uzmu u obzir i objektivni i subjektivni elementi postupanja sudionika odštetnopravnog odnosa. U krajnjoj liniji, u sustavu objektivizirane nepažnje, kakav poznaje naše pravo, objektivni element protupravnosti (protivnost pravnom pravilu) i subjektivni element protupravnosti (štetnikova krivnja, odnosno povreda dužne pažnje) vrlo često će predstavljati tek dva lica jedne te iste medalje, tako da će u velikom broju slučajeva, utvrđujući jedan od ta dva elementa, sudovi ujedno utvrđivati i drugi.

Ono što je posebno zanimljivo jest da sudska praksa jasno upućuje na to da se kriterij dužne pažnje uobičajeno koristi pri utvrđivanju protupravnosti u objektivnom smislu čak i u slučajevima koji se prosuđuju prema pravilima objektivne odgovornosti. ${ }^{102}$ Naime, posebni propisi, poglavito oni iz domene sigurnosti prometa, nameću adresatima tih propisa niz dužnosti postupanja pa se, utvrđujući nečiju protupravnost u objektivnom smislu prema tim propisima, sudovi ujedno vrlo često bave utvrđivanjem jesu li sudionici tih odnosa postupali s dužnom pažnjom. No, time se ujedno brišu jasne granice između subjektivne i objektivne odgovornosti za štetu.

Sumirajući navedene stavove hrvatske sudske prakse načelno bi se moglo zaključiti da je protupravnost strukturno složen institut koji u sebi ujedinjuje niz objektivnih i subjektivnih elemenata procjene nečijeg postupanja, kojim

101 Vidi presudu Rev 2315/1990-2, supra 5.

102 Vidi presude Rev 724/1991-2, Rev 735/05-2, supra 5. 
se nastoji osigurati da se pripadnici određenog društva ponašaju u skladu s normama toga društva, odnosno da se sankcionira ono postupanje koje vrijeđajući te društvene norme prouzrokuje drugome štetu. Protupravnost nečijeg postupanja ne ogleda se samo u povredi zakonskih normi, već i u povredi svega onoga što se može izraziti u normi obzirnog ponašanja u određenom društvu (norme de civilité). ${ }^{103} \mathrm{U}$ tom smislu protupravno će postupati onaj kome se može uputiti prijekor da se nije ponašao adekvatno, onako kako se od njega to očekivalo, odnosno da je svojim ponašanjem prekršio obvezu obzirnog postupanja. Pritom, da bi se nekome takav prijekor mogao uputiti, nužno će biti uzeti u obzir i objektivne i subjektivne kriterije procjene nečijeg postupanja. Takvo shvaćanje pojma protupravnosti vodi, međutim, do zaključka da je naš pojam protupravnosti doista analogan francuskom institutu faute.

\section{LITERATURA}

\section{Knjige i članci:}

Klarić, P.; Vedriš, M., Građansko pravo, Narodne novine, Zagreb, 2014.

Crnić, I., Zakon o obveznim odnosima, Organizator, Zagreb, 2006.

Baretić, M., Tort Law, u: Josipović, T. (ur.), Introduction to the Law of Croatia, Wolters Kluwer, Alphen aan den Rijn, 2014., str. 161 - 190.

Baretić, M., Croatia, u: Karner, E.; Steininger, B. (ur.), European Tort Law 2015, de Gruyter, Berlin, Boston, 2016., str. 76 - 100.

Gorenc, V. et al., Komentar Zakona o obveznim odnosima, RRiF, Zagreb, 2005.

Stipković, Z., Protupravnost kao pretpostavka odgovornosti za štetu, Pravni fakultet Sveučilišta u Zagrebu, Zagreb, 1991.

Gliha, I., Protupravnost kao pretpostavka odgovornosti za štetu nastalu u športu, Privreda i pravo, vol. 32, 1993., str. 945 - 954.

Gliha, I.; Baretić, M.; Nikšić, S., Pure Economic Loss in Croatian Law, u: Bussani, M. (ur.), European Tort Law, Eastern and Western Perspectives, Stämpfli, Ant. N. Sakkoulas, Sellier, Bruylant, Bern, Brussels, Athens, 2007., str. 249 - 293.

Galev, G.; Dabović-Anastasovska, J., Obligaciono pravo, Univerzitet „Sv. Kiril i Metodij“ Skopje, Praven Fakultet „Iustinijan Prvi“, Skopje, 2012.

Bikić, A., Naknada štete, Pravni fakultet Sarajevo, Sarajevo, 2010.

Antić, O., Obligaciono pravo, Službeni glasnik, Beograd, 2009.

103 Tako i Stipković, op. cit. u bilj. 4, str. 60. 
Martín-Casals, M.; Ribot, J., Compensation for Pure Economic Loss under Spanish Law, u: van Boom, W. N.; Koziol, H.; Witting, C. A. (ur.), Pure Economic Loss, Springer, Wien, New York, 2004., str. 62 - 72.

Blagojević, B. T.; Krulj, V., Komentar Zakona o obligacionim odnosima, Savremena administracija, Beograd, 1980.

Emmerich, V., BGB Schuldrecht-Besonderer Teil, 12. Auflage, C.F. Müller Verlag, Heidelberg, 2009.

\section{Propisi:}

Hrvatska

Ustav Republike Hrvatske, NN 56/90, 135/97, 8/98, 113/00, 124/00, 28/01, 41/01, 55/01, 76/10, 85/10, 05/14 (dostupno na: www.nn.hr)

Zakon o potvrđivanju Konvencije za zaštitu ljudskih prava i temeljnih sloboda i protokola br. 1., 4., 6., 7. i 11. uz Konvenciju za zaštitu ljudskih prava i temeljnih sloboda, NN 18/97 (dostupno na: www.nn.hr)

Zakon o obveznim odnosima, NN 35/05, 41/08, 78/15, 29/18 (dostupno na: www.nn.hr)

Zakon o parničnom postupku, SI SFRJ 4/1977, 36/1977, 6/1980, 36/1980, 43/1982, 69/1982, 58/1984, 74/1987, 57/1989, 20/1990, 27/1990, 35/1991, NN 53/1991, 91/1992, 58/1993, 112/1999, 88/2001, 117/2003, 88/2005, 02/2007, 84/2008, 96/2008, 123/2'08, 57/2011, 148/2011, 25/2013, 89/2014, 70/2019 (dostupno na: www.nn.hr)

Zakon o rudarstvu, NN 56/13, 14/14, 52/18, 115/18, 98/19 (dostupno na: www. nn.hr)

Zakon o odgovornosti za štetu nastalu uslijed terorističkih akata i javnih demonstracija, NN 117/03 (dostupno na: www.nn.hr)

Njemačka

Bürgerliche Gesetzbuch (dostupno na: https://www.gesetze-im-internet.de/bgb/)

Francuska

Code civil (dostupno na: https://www.legifrance.gouv.fr/codes/texte_lc/LEGITEXT000006070721)

Austrija

Allgemeines bürgerliches Gesetzbuch (dostupno na: https://www.jusline.at/gesetz/abgb) 
Italija

Codice Civile (dostupno na: https://www.gazzettaufficiale.it/anteprima/codici/ codiceCivile)

Švicarska

Obligationenrecht (dostupno na: https://www.gesetze.ch/inh/inhsub220.htm)

\section{Sudske odluke:}

Vrhovni sud Republike Hrvatske

Rev-x 544/2012-2 od 19. rujna 2012. godine

Rev 1306/06-2 od 28. veljače 2007. godine

Rev 635/08-2 od 08. rujna 2009. godine

Gzz-39/03-3 od 27. svibnja 2003. godine

Rev-503/08-2 od 21. svibnja 2008. godine

Rev 1535/1990-2 od 9. siječnja 1991. godine

Rev 976/2007-2 od 9. siječnja 2008. godine

Rev 713/98 od 13. rujna 2000. godine

Rev x 32/2010-2 od 27. listopada 2010. godine

Gzp 1014/09-3 od 16. veljače 2010. godine

Rev 1143/2004-2 od 4. siječnja 2006. godine

Rev 92/2008-2 od 10. rujna 2009. godine

Rev 242/2003-2 od 4. lipnja 2003. godine

Rev 917/1990-2 od 12. rujna 1990. godine

Rev 1671/1990-2 od 13. prosinca 1990. godine

Rev x 103/08-2 od 17. prosinca 2008. godine

Rev 2315/1990-2 od 4. lipnja 2003. godine

Rev 724/1991-2 od 19. veljače 1991. godine

Rev 735/05-2 od 5. listopada 2005. godine

Rev 1210/09-2 od 27. travnja 2011. godine

Rev 613/1993-2 od 16. veljače 1994. godine

Rev 909/2008-2 od 23. veljače 2010. godine 
Županijski sud u Zagrebu

Pn-7434/05 Gžn-1606/11 od 19. srpnja 2011. godine

Pn-6472/00 Gžn-2882/07 od 15. rujna 2009. godine

Pn-1122/07 Gžn-3740/08 od 24. svibnja 2011. godine

Pn-4181/6 Gžn-3905/08 od 16. prosinca 2008. godine

Pn-6956/06 Gžn-1934 od 19. listopada 2010. godine

Županijski sud u Varaždinu

Gž-2584/14-2 od 5. listopada 2015. godine 


\section{Summary}

\section{Marko Baretić}

\section{UNLAWFULNESS AS A CONDITION FOR TORT LIABILITY IN CROATIAN LAW}

The paper analyses, through the lens of case-law, some basic questions relating to unlawfulness in Croatian tort law, such as: Is unlawfulness a condition for liability? What are the elements of unlawfulness? What does unlawfulness relate to? What is the relationship between unlawfulness and fault? Based on what criteria should unlawfulness be assessed? The analysis conducted in this paper undoubtedly demonstrates that unlawfulness is a much more complex and dynamic notion than suggested in Croatian legal literature. In this respect, the analysis suggests that, when assessing unlawfulness of a tortfeasor's actions, courts in Croatia often rely on some subjective elements legal literature commonly associates with fault. Furthermore, the analysis also demonstrates that, in the course of assessing unlawfulness of a tortfeasor's actions, courts in Croatia often take into consideration a number of elements, such as the nature and importance of the rights and interests involved, the level of peril involved in a particular activity, the level of violation of protective norms, availability of alternative protection measures, foreseeability of damage, but also the interplay between these elements. All this leads the author to the conclusion that the notion of unlawfulness, as understood in Croatian case-law, closely resembles the French notion of faute.

Key words: unlawfulness, tort law, conditions for liability

* Marko Baretić, Ph. D., Professor, Faculty of Law, University of Zagreb, Trg Republike Hrvatske 14, 10000 Zagreb, Croatia; marko.baretic@pravo.hr;

ORCID ID: orcid.org/0000-0001-8182-0315 